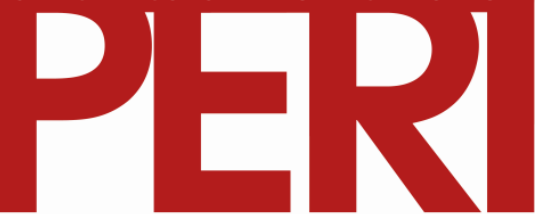

University of Massachusetts Amherst

\title{
Privatization and the Postsocialist Fertility Decline
}

Gabor Scheiring, Bryant P. H. Hui, Darja Irdam, Aytalina Azarova, Eva Fodor, David Stuckler, Gosta Esping-Andersen, and Lawrence King

December 2020

\section{WORKINGPAPER SERIES}


Privatisation and fertility

\title{
Privatization and the postsocialist fertility decline
}

\author{
Gabor Scheiring[1]*, Bryant P. H. Hui[2], Darja Irdam[3], Aytalina Azarova[3], Eva Fodor[4], \\ David Stuckler[1], Gosta Esping-Andersen[1], Lawrence King[5] \\ [1] Bocconi University, Department of Social and Political Sciences \\ [2] The University of Hong Kong, Department of Sociology \\ [3] University of Cambridge, Department of Sociology \\ [4] Central European University, Democracy Institute and Department of Gender Studies \\ [5] University of Massachusetts Amherst, Department of Economics \\ *Corresponding author: gabor@gaborscheiring.com
}

\section{Keywords}

Privatization; Uncertainty; Fertility; Social Reproduction; Eastern Europe

\begin{abstract}
In this article, we analyze the privatization of companies as a potential but so far neglected factor behind the postsocialist fertility decline. We test this hypothesis using a novel database comprising information on the demographic and enterprise trajectories of 52 Hungarian towns between 1989-2006 and a cross-country dataset of 28 countries in Eastern Europe. We fit fixed and random-effects models adjusting for potential confounding factors and control for time-variant factors and common trends. We find that privatization is significantly associated with fertility decline, explaining approximately half of the overall fertility decline across the 52 towns and the 28 countries.
\end{abstract}




\section{Funding}

The authors acknowledge the financial support of The European Research Council (ERC) [grant number 269036]. GS also acknowledges the financial support of the Cariplo Foundation (Fondazione Cariplo) in the framework of the POTES project (Enhancing the attractiveness of Lombardy through the Excellence of Health Economics Research) [Ref. 2017-2077], co-founded by the Lombardy Region. The funding bodies had no role in study design, data collection, data analysis, and reporting of this study.

\section{Acknowledgments}

We are grateful to János Köllö and his colleagues and the Institute of Economics of the Hungarian Academy for their help with data collection. 


\section{Privatisation and fertility}

\section{Introduction}

The ten countries with the fastest shrinking populations worldwide are all located in Eastern Europe (United Nations 2017). The population of Bulgaria, Poland, and Romania, among others, is expected to decline by more than $15 \%$ between $2017-2050$. Hungary's population is also projected to drop by a similar rate, from 9.7 million to 8.3 million between 2017-2050 (United Nations 2017:25). In addition to elevated mortality (Scheiring et al. 2019), emigration (Black et al. 2010), and the declining number of women of childbearing age, low fertility is the leading cause of population decline (Billingsley and Duntava 2017).

The transition from socialism to capitalism had profound effects on families and childbirth. The total fertility rate (TFR, henceforth fertility) ${ }^{1}$ in Eastern Europe reached its lowest point in the 1990s and 2000s, dropping below 1.3 in several countries (Kohler et al. 2002). Most dramatically, the number of live births in East Germany (GDR) fell by 46\% between 1989-1991 (Eberstadt 1994). Such a dramatic drop in fertility is unprecedented for industrialized societies in peacetime and had only been observed at times of war or famine (Cornia and Paniccia 1995).

While more gradual than in its neighboring countries, the 32\% fertility drop in Hungary during the first decade of the transformation (1990 to 1999) was still massive by international standards. Fertility reached its nadir in 2003 (1.27). In 2009 (i.e., 20 years after the fall of the Berlin Wall), it stood at 1.32, the second-lowest in Europe and only surpassing Moldova in that year. As Figure 1 shows, the decline marks a significant break with the previous fertility trend, which marked periods of slow decline and stability before the transition (Aassve et al. 2006:128). While during the 1980s, TFR only declined by four percentage points, fertility within the 20-24 age group dropped almost by 50\% between 1990-2001 (Aassve et al. 2006). During the first decade of the transformation, the mean age of mothers at first birth increased by four years (Spéder and 


\section{Privatisation and fertility}

Kamarás 2008), and the rate of second births also decreased (Billingsley and Duntava 2017; Kohler et al. 2002; Sobotka 2011; Spéder and Kamarás 2008). The decline of the total fertility rate cannot be reduced to the tempo effect, i.e., the postponement of the first child. The adjusted total fertility rate (TFRp) that filters out the tempo effect has also dropped from 1.8 in 2005 to under 1.4 in 2010 (Tálas 2020).

\section{Figure 1 here}

The postsocialist fertility decline is a topic of ongoing debate. Considerable disagreement continues to exist concerning the underlying social causes and the mechanisms that link socioeconomic transformation to fertility decline (Kohler and Kohler 2002). Some studies connect the fertility decline to the postsocialist economic crisis, pointing to the role of unemployment, declining incomes, inflation, and welfare state retrenchment (Aassve et al. 2006; Billingsley 2010; Cornia and Paniccia 1995; Macura et al. 2000). Others propose that the fertility decline results from the second demographic transition, the adoption of Western values prioritizing autonomy, individualism, and consumerism, which weaken the family (Lesthaeghe and Surkyn 2002; Thornton and Philipov 2009). Some studies posit that the new economic opportunities, especially women's rising education and employment, increased the opportunity cost of having children (Perelli-Harris 2008; Spéder and Bartus 2017).

While this extensive body of research has uncovered essential trends and causal mechanisms, empirical evidence suggests that none of these three explanations is entirely satisfying. Mirroring trends in the West (Bongaarts 2001), desired fertility has remained relatively constant in most postsocialist countries; thus, the postmodernization of values has a limited explanatory capacity (Szalma and Takács 2018). In Hungary, the female to male employment ratio dropped by 16 percentage points from the late 1980s to the early 2000s (World Bank 2020). 


\section{Privatisation and fertility}

Therefore, though economic opportunities might depress fertility, they cannot be a major reason for the massive fertility drop. Finally, the postsocialist economic recession ended a decade earlier than the fertility decline, making it a partial explanation at best (Billingsley 2010). In sum, there remain many unknowns, especially about the distal social and economic determinants of the postsocialist fertility decline (Frejka and Gietel-Basten 2016; Spéder and Kapitány 2014).

We suggest that company privatization ${ }^{2}$ acts as a major, unanticipated demographic shock to fertility, primarily because it catalyzes uncertainty, shifts the cost of care work onto families, and reduces their resources available for social reproduction. Although scholars have investigated the role of privatization in mortality (Azarova et al. 2017; King et al. 2009; Scheiring et al. 2018; Stuckler et al. 2009), thus far, its potential role in fertility decline has yet to be studied. Addressing this gap in the existing knowledge is vital for two reasons.

First, the role of company privatization is particularly relevant in former socialist countries. In state-socialist economies, socialist companies acted as stabilizers of everyday lives and maintained a social environment conducive to having children. They contributed to reducing economic uncertainty (long-term job stability, high female employment, guaranteed employment following maternity leave), socializing the cost of care work (free childcare provision, extended maternity leaves), and provided resources that help social reproduction (subsidized housing, holiday facilities, cultural services). Hence, the privatization of these socialist companies potentially influences fertility in profound ways. Analyzing these mechanisms could improve scholarly knowledge about the postsocialist fertility puzzle, particularly the gendered nature of the transition’s demographic impact.

Second, the relevance of privatization goes beyond the postsocialist region. Privatization policies are still widely implemented around the globe. Between January 2014 and August 2015, 


\section{Privatisation and fertility}

global privatization proceeds reached $\$ 431.4$ billion, far more than any comparable period since the beginning of the UK privatization programs in the late 1970s (Estrin and Pelletier 2018). As we argue, companies and enterprises form an essential part of the institutional environment that mediates the tension between work and family, a point ignored by much of the literature that focuses on the welfare state as the critical institution of de-commodification.

This paper presents the first analysis of the association between company privatization and fertility. We weave together theoretical ideas from Polanyi, Esping-Andersen, and Fraser, utilizing the concepts of decommodification and commodification to highlight the role of privatization in the postsocialist fertility decline. We analyze the association between privatization and fertility at two levels: across towns in Hungary and countries in Eastern Europe.

First, we adopt a unique approach, linking companies to towns to analyze town-level fertility change. Although Hungary ended up with one of Europe's lowest fertility rates by the end of the 2000s, it recovered quickly from the transition recession. Thus, some researchers believe that economic factors do not play a major role in the fertility decline (Billingsley 2010; Sobotka 2003). Consequently, Hungary represents a contradiction between apparent economic recovery and substantial fertility decline, representing a strategic case to analyze the association between privatization and fertility.

Next, we analyze the impact of privatization across 28 former socialist-bloc countries for the 1989-2012 period. We link data from the EBRD’s Transition Indicators database on privatization to country-level fertility rate, controlling for relevant socio-economic and demographic variables. Due to the novelty of our data on privatization and the breadth of demographic variables, we regard the town-level models as the superior strategy methodologically, 


\section{Privatisation and fertility}

yielding more reliable results. However, the cross-country regressions offer a vital robustness check and greatly increase the findings’ relevance and validity.

The paper is structured as follows. The next section reviews the existing interpretations of the postsocialist fertility decline in more detail and points out the need for a new approach that focuses on company privatization. The subsequent section outlines our theoretical framework, locates it in the broader sociological literature, and identifies the critical components of the causal mechanism. The paper then continues describing the data, the analytical strategy, the variables, and modeling. The subsequent section presents the results of fixed and random effects models and various robustness checks, including a cross-country test of the privatization-fertility association in the postsocialist region. Finally, we conclude by interpreting the results in light of the relevant literature, evaluating mechanisms derived from different theoretical approaches, pointing out the contributions to the sociological literature and the policy implications.

\section{Theories of the postsocialist fertility decline}

There are three strands of research on the determinants of the postsocialist fertility decline. The first is the second demographic transition approach (henceforth SDT approach), which highlights the role of cultural change (Lesthaeghe and Surkyn 2002; Sobotka 2003; Thornton and Philipov 2009) as a crucial determinant of fertility. Some argue that the diffusion of Western postmaterialist values, such as the beliefs that "marriage is an outdated institution" and "children are not necessary for life fulfillment,” are particularly problematic for fertility (Lesthaeghe and Surkyn 2002). Others add that the transition entails "normative deregulation" and anomie, which creates uncertainty and leads to fertility decline (Philipov et al. 2006). Some even assert that the declines in fertility and marriage rates are "normal and even necessary characteristics of modern democratic societies.” (Rabusic (1996) quoted in Kohler and Kohler 2002:234-35) 


\section{Privatisation and fertility}

However, family-related values and fertility preferences did not change much in most postsocialist countries; thus, the second demographic transition cannot explain the massive drop in fertility (Rotariu 2006; Szalma and Takács 2018). Surveys found that although the overwhelming majority of Hungarian women associated having children with a happy life, the chances of realizing their fertility intentions were much lower than in Western countries (Spéder and Kapitány 2014). In 1999, 86\% of Hungarian women thought that having two, three, or four children was ideal (Kamarás 2003), but had to forego having more children despite their preferences (Hollos and Bernardi 2009). Moreover, countries that have progressed towards postmodern family values have higher fertility levels in Europe than more traditional societies (Aassve et al. 2013; Mcdonald 2006). A “postmodern” value shift towards more gender equality and the accompanying equalization of household workload seems to be an important factor behind the rise of fertility in Nordic countries as opposed to more traditional societies (Arpino et al. 2015; Brinton and Oh 2019; Oláh 2003).

The second perspective focuses on new economic opportunities (henceforth the economic opportunity approach). The key argument here is that women's employment, education, and consumption opportunities increase the "opportunity cost" of having children (Brewster and Rindfuss 2000). Economic modernization, rising incomes, and the growth of service sector employment have also been associated with fertility decline outside the postsocialist context (Bollen et al. 2007). From 1991 to 2001, the ratio of full-time students aged 20 rose from 14\% to 33\%, continuing to grow until 2006 (Spéder and Kamarás 2008). Gross female tertiary education enrolment surged from 16.2\% in 1989 to $80.6 \%$ in 2006 (World Bank 2020). ${ }^{3}$ Several empirical studies reported a negative association between women’s participation in education (Aassve et al. 


\section{Privatisation and fertility}

2006; Kohler et al. 2002; Perelli-Harris 2008; Spéder and Bartus 2017), the labor market (Kohler and Kohler 2002) and fertility.

However, there is contrasting evidence that women's labor force participation is not strongly associated with fertility (Matysiak and Vignoli 2008). Its impact depends on the degree of equality in the domestic division of labor, i.e., a more equal domestic division of labor makes women’s labor market participation more compatible with child-rearing (Arpino et al. 2015; Craig and Mullan 2011; Oláh 2003). Overall, female employment during the transition declined, and the female to male employment ratio dropped by 16 percentage points (World Bank 2020), which implied a retraditionalisation of the gender division of work. This suggests that women's employment is not likely to be a significant cause of the dramatic fertility decline. Concerning education, the initial negative association between education and fertility has weakened and even reversed in some cases (Axinn and Barber 2001; Kravdal and Rindfuss 2008; Rindfuss et al. 2003). Evidence in the postsocialist context also suggests a positive relationship between women's education and the decision to have a second child (Bartus et al. 2013; Spéder 2006).

The third approach centers on the role of the transition-related economic crisis (the economic crisis approach). Research suggests that income loss, unemployment, and thwarted consumption expectations caused a postponement of childbearing and contributed to the fertility decline in Eastern Europe (Aassve et al. 2006; Billingsley 2010; Cornia and Paniccia 1995; Ellman 2000; Macura et al. 2000). However, others assert that the economic crisis approach could only explain the fertility decline during the first few years of the transformation (Lesthaeghe and Surkyn 2002). East-Central European countries, such as the Czech Republic, Hungary, Poland, and Slovenia, witnessed economic recovery soon after the abrupt transition crisis but continued to suffer from fertility decline until the 2000s (Billingsley 2010; Ellman 2000; Sobotka 2003). The 


\section{Privatisation and fertility}

association between income and fertility is also ambiguous as couples in the lowest income quintile had more children than those in Hungary's highest quintile in the 1990s (Aassve et al. 2006). Concerning unemployment, research found that macro-level data underpin the negative association between unemployment and fertility, but individual-level measures of unemployment are associated with increased fertility in Russia (Kohler and Kohler 2002).

A strand of the economic crisis approach emphasizes changes in the welfare state instead of macro-economic fluctuation. Empirical research has identified the negative impact of welfare state transformation and retrenchment on fertility and, more generally, on families' well-being (Fodor 2002; Fodor 2004; Haney 2002; Spéder and Kamarás 2008). In 1995, the Socialist-Liberal government overhauled family policies by eliminating wage-related parental leave benefit (GYED) and introducing means testing for family allowances. ${ }^{4}$ Although the successive conservative government reversed some of these changes within two years, some argue that these changes eroded trust in family policies, which adversely affected fertility (Aassve et al. 2006). Despite the significant reduction in the early 1990s, spending on family policy hovered around 2.1\% of the GDP between 1995-2010 (Eurostat 2020). Thus, it is not plausible that declining family support could be a major determinant of the secular fertility decline.

We argue that privatization is a crucial but neglected factor behind the postsocialist fertility decline. In their paper on privatization and mortality, King et al. (2006) found a statistically significant association between fertility and mass privatization in cross-country regressions but did not present the results or further elaborate the association. ${ }^{5}$ Thus, a precise analysis of the link between the privatization of companies and fertility is lacking. This omission partly stems from data limitations since town or regional-level information on companies is hard to obtain. Hence, extensive efforts to link town-level privatization to demographic trends are needed. 
Privatisation and fertility

\section{The privatization-fertility mechanism}

We build on the literature that emphasizes the role of economic uncertainty and the institutional environment mitigating it. Non-commodified institutions are crucial to mitigate the inherent tension between economic production in the realm of market exchange and social reproduction ${ }^{6}$ in families (Bhattacharya 2017; Fraser 1994; Orloff 1993). For social reproduction, families (mostly women) produce “free” public goods that underpin wage labor and market-based production (Fraser 2013). Socializing the burden of care work can increase fertility, improve women’s independence (Esping-Andersen and Billari 2015; Oláh and Bernhardt 2008; Vos 2009), and reduce the burden of balancing work and child-rearing (Glass et al. 2016). However, the state is not the only institution that can relieve the tension between economic production and social reproduction. We highlight the companies' role, more specifically, the decommodifying effect of company-level welfare arrangements in securing a social environment conducive to having children, and how the retrenchment of these depresses fertility. ${ }^{7}$

Socialist companies were a separate form of “de-commodification mechanism” (EspingAndersen 1990) that has been so far neglected. Russian enterprises spent around 3-5 percent of GDP on social provision, while East European firms spent about half this amount, which is still very significant (Cook 2007:39-40). While economic reforms in Hungary’s “late-socialist mixed economy" strengthened the role of foreign, inter-company, and informal market exchange mechanisms, the market remained a secondary coordination mechanism (Szelényi 1991), offset by the decommodification mechanisms of the state and the companies. Company-based decommodified services were universal and legally prescribed. As the reforms from the end of the 1980s emancipated the market from its secondary role, these decommodification functions became untenable. The state took over some but ceased most of them. 


\section{Privatisation and fertility}

Figure 2 here

Figure 2 presents an overview of the hypothesized causal mechanism between the privatization of companies and declining fertility. First, privatization may lead to increased uncertainty (1). Socialist companies represented a stable form of employment, a lower intensity of work, and the prospect of a lifetime job. Following Mills and Blossfeld (2005), we differentiate between two forms of uncertainty, ${ }^{8}$ financial uncertainty (the potential of declining income and losing a job) and temporal uncertainty (instability of work arrangements, short- or fixed-term contracts, temporary work). Privatization may increase financial uncertainty (1a). Socialist companies faced soft budget constraints (Kornai 1986), i.e., they could rely on state resources to cover losses. In the absence of hard budget constraints, state enterprises rewarded lower-skilled labor better than their private-sector counterparts and offered relatively more generous nonwage benefits (Kikeri 1997). Consequently, privatization may also widen upward and downward mobility channels and increase income inequality (Bandelj and Mahutga 2010; Birdsall and Nellis 2003; Cuadrado-Ballesteros and Peña-Miguel 2018; Mahutga et al. 2017). These uncertainties imply that future income streams may become less predictable. A growing evidence links income inequality (Cherlin et al. 2016) and financial uncertainty to declining fertility (Adler 1997; Mcdonald 2006; Oppenheimer 1988).

Privatization also may increase temporal uncertainty (1b). One of the arguments for privatization is to increase pressure on companies to improve efficiency by reducing overstaffing. Privatized companies have more incentive than state-owned enterprises to shed labor and decrease labor costs (Kikeri 1997; Ramamurti 1997; Stošić et al. 2012). In the long term, privatization might contribute to reduced unemployment but only after a period of increased short-term uncertainty (Cuadrado-Ballesteros and Peña-Miguel 2018). The research on what kind of jobs people find after 


\section{Privatisation and fertility}

dismissal from public enterprises is scant. However, evidence suggests longer working hours, less secure tenure, and a move to short and fixed-term contracts (Birdsall and Nellis 2003; McKenzie et al. 2003), facilitating the spread of precarious work arrangements (Kalleberg 2009). Privatization intensifies competition, pushing industrial relations toward greater labor flexibility (Streeck 1987). These temporal uncertainties rooted in precarious employment also influence fertility. Kreyenfeld (2010) found that highly educated women postpone parenthood when subject to employment uncertainties. Youth with lower levels of job security (i.e., self-employed, private sector, temporary contract, irregular shifts) are less able to make long-term binding commitments such as parenthood (Mills and Blossfeld 2005). Unstable and unpredictable work schedules generate more complex logistical challenges for arranging care, potentially reducing fertility intentions (Harknett et al. 2020; Schneider and Harknett 2020). The psychological stress caused by temporal uncertainty might also be associated with male infertility (Nargund 2015).

Second, the privatization of socialist enterprises may shift the cost of care work onto families (2). Socialist companies contributed to socializing the cost of care work by providing food to workers in the canteens, organizing childcare and summer camps for children, operating nurseries and kindergartens, and allowing more flexible working hours for mothers who return to work after giving birth. Daycare facilities were often linked to companies. Thus, when factories were closed or privatized, women not only lost their jobs but often daycare for their children too (Adler 1997). Some of these facilities are now maintained by the state, the local government, or local communities. Even families they did not lose immediate access to it, they lost the prospect of daycare for future children, as state facilities become increasingly overcrowded, which increases the uncertainty for families to get a place at all. Leaving the responsibility for daycare to the family means more work and less willingness to increase workload by having more dependents. Research 


\section{Privatisation and fertility}

found strong tension between paid work and unpaid (care) work in Hungary, including childcare and elderly care, particularly significant within the lower social classes (Gregor and Kováts 2019). Unpaid care responsibilities and the declining access to public or private care services intensifies the conflict between work and having children, potentially weakening fertility intentions (Brewster and Rindfuss 2000; Esping-Andersen 2009; Gerber and Perelli-Harris 2012; Hook and Paek 2020; Pesando 2019).

Third, privatization might also erode the collective resources provided by socialist stateowned companies that families could indirectly rely on for social reproduction (3). These collective resources included subsidized housing and holidays, as well as cultural and recreational services (3a). Companies and trade unions owned outlets at recreational spots that people could visit each year free or for a greatly subsidized price. Privatization significantly reduces access to these facilities, increasing the cost of recreation. Privatization means that "non-essential” cultural and sports services are outsourced to the state, and most of these services connected to companies are shut down, weakening towns’ local sports and cultural life (Scheiring et al. 2020b). This reduced access to services again increases the cost of recreation and reduces the resources available for social reproduction. State-owned socialist companies also contributed to housing either directly or through loan subsidies. Although the access to socialist housing was unequal, it was more affordable and facilitated residential stability (Szelényi 1983). Following the restructuring of stateowned enterprises, and the complete privatization of public housing, the cost of securing a roof to live under is shifted to families, leading to high indebtedness (Bohle 2014). There seems to be a clear positive gradient between couples' fertility intentions and the degree to which they feel secure about housing (Vignoli et al. 2013). In China — experiencing economic restructuring comparable 


\section{Privatisation and fertility}

to Hungary's — fertility appears to be higher in cities where housing is more affordable, whereas higher housing prices reduce the willingness to have children (Pan and $\mathrm{Xu} 2012$ ).

The collective resources provided by companies also included facilitating the emergence of workplace and neighborhood communities, which are also eroded by privatization (3b). Communities and informal networks provide help and other material and non-material resources (money, goods, services, informal child care opportunities) that help to cope with the challenges of managing a household and raising children. Conversely, privatization may lead to social disintegration, which wreaks havoc with everyday lifeworlds and working-class communities, and increases everyday hostilities and alienation (Bartha 2013; Burawoy and Verdery 1999; Hann 2002). Empirical research showed that privatization of community services such as recreation might result in more spatially limited social capital, where individuals are less willing to cooperate for the common good (Champlin 1999). The same processes of economic restructuring were also shown to lead to the erosion of local and company communities in Hungary’s medium-sized towns (Scheiring 2020). Conversely, the erosion of social capital might have been a significant factor behind the fertility decline in Eastern Europe (Bühler and Fratczak 2007; Philipov et al. 2006).

Based on these considerations, we expect that privatization is significantly associated with reduced fertility in postsocialist Hungary. It is not the presence of private markets per se, but the shift towards more commodified company arrangements that lead to a decline in fertility. Thus, once privatization slows down, fertility should stabilize at a lower level. 


\section{Privatisation and fertility}

\section{Methods}

\section{Data}

Having children is an individual- or family-level decision. Therefore, most studies on fertility rely on individual-level surveys. However, by design, these studies cannot account for the role of contextual factors, such as privatization, which can only be measured at enterprise, town, or country levels. Macro-level analysis using data on countries (as in Arpino et al. 2015) is less common because of the large room it leaves for ecological bias. A recent innovative study has analyzed the political determinants of fertility in Turkey using local-level data (Aksoy and Billari 2018). Following this approach, our analysis focuses on Hungarian towns. The impact of privatization can be modeled more accurately at the town-level than at the national level. We link company-level information obtained from public and private registries to vital town-level statistics and economic data obtained from the Hungarian Central Statistical Office.

Our research builds on the Privatization and Mortality (PrivMort) project, which is a multilevel study on the demographic consequences of the postsocialist economic change (Irdam et al. 2016; Scheiring et al. 2020a). Our research covers the years between 1990-2006, a period during which governments carried out the major institutional reforms related to the transition from socialism to capitalism, including privatization. We analyze the pre-2006 period because a new cycle of domestic political and economic crisis began after 2006, leading to a new regime of accumulation after $2010 .^{9}$

Based on the data from the Hungarian Central Statistical Office (HCSO), we identified towns with 5,000-100,000 inhabitants and industrial employment exceeding $30 \%$ of total employment ( $\mathrm{N}=110)$. We omitted towns close to Budapest to eliminate bias related to the high 


\section{Privatisation and fertility}

concentration of economic activity in the capital. From this set of towns, we randomly selected 52 towns for further analysis. Hungary only has nine cities with more than 100,000 inhabitants - they likely experienced different socio-economic trajectories that the sampled towns. However, we do not claim that our sample represents the experience of Hungary as a whole. A bigger sample with data on more towns and companies would have required more resource-intensive fieldwork, which would have been beyond an already large research project’s practical limits.

We then collected detailed information on economic, social, demographic, religious, cultural, and health-related factors from the HCSO. Certain data are available in annual time series, while others only from the 2001 census. We use the total fertility rate (TFR) as the outcome variable. TFR is not an ideal measure. It does not allow us to analyze if people are postponing parenthood, having longer intervals between children, or having stopped having as many children as before. Although TFR has limitations, we use it because we study the effect of privatization, which we theorize to operate in a period fashion simultaneously experienced by women of all childbearing ages. Thus TFR is an adequate measure to capture the overall effect of privatization. Other fertility indicators are not available at the town level as part of the research project. We also collected additional data on national-level socio-economic trends from the World Bank’s World Development Indicators database. In 2001, there were altogether 456,679 women aged 15-64 living in the 52 towns. Table A1 in the appendix presents the descriptive statistics for the variables used in the analysis.

Next, we collected information on the privatization of major companies in these 52 towns. Since company ownership information was not available in digital form fully covering the first few years of the transition, we had to obtain this data from the non-digital archives at the local courts of registry. ${ }^{10}$ To make such a project practically feasible, we identified the five largest 


\section{Privatisation and fertility}

companies in terms of the number of employees in each selected town. Then we collected data on their ownership structures and key economic characteristics (number of employees, economic branch, dates of bankruptcy, and termination procedures), spending more than two years obtaining these data.

Overall, we analyze ownership history data from 260 companies, i.e., 550 companies separately counting the successor and parent companies. From 1989 to 2006, the total number of employees of the five largest companies in each town represented $57.9 \%$ of the town-level industrial employment in 1989 on average. Thus, on average, the five largest companies capture most of the industrial labor force and were, therefore, the most important economic entities that influenced the towns’ lives.

Our company selection strategy concentrates on ex-socialist companies that were stateowned before 1989. New small companies formed alongside state-owned companies during the transition do not form part of the sample. This selection is justified by our theoretical interest, as we are specifically interested in the effect of privatization, and not the effect of ownership composition of local economies in more general. Privatization involves the transfer of assets and the concomitant restructuring of companies. Newly established private companies that have full private ownership on day zero are not privatized. Their effect on fertility is different from privatization, as they were never legally obliged to provide the services whose importance for fertility we stressed in the previous section.

The fully balanced dataset has almost no $(<1 \%)$ missing data. Most variables cover every town-year in the dataset, except the first year (1989), for which we rely on more on limited data. However, the primary independent variable is available from 1989 with several other control variables related to the economy. Although demographic and health variables are only available 


\section{Privatisation and fertility}

from 1990, it is not a problem as we apply a one-year lag for the privatization variable, i.e., privatization in 1989 affecting fertility in 1990. A few data points are missing for certain less critical town-level annual control variables. ${ }^{11}$ We have no reason to believe that these few missing data points would significantly influence the statistical behavior of the fitted models.

At the next level of analysis, we created a separate cross-country dataset with country-level time-series data obtained from the World Bank’s World Development Indicators (WDI) database. Data include annual time series on the total fertility rate, population size, economic processes, modernization, demographic trends, health, and female opportunity. We use the country-level total fertility rate as the dependent variable. We extend the WDI data with information on privatization from the EBRD’s Transition Indicators database, which includes, among others, a small-scale and a large-scale privatization index.

According to the EBRD, the value of the privatization index is 1 if there is little private ownership and privatization schemes have not yet been implemented. The value of the privatization index is 4 if 50\% of state-owned enterprise and farm assets are in private ownership, and significant progress is made with corporate governance reforms. Anything above 4 implies standards typical of advanced industrial economies: more than $75 \%$ of enterprise assets in private

ownership with effective corporate governance. We calculated the mean of the two indexes and used this as the primary independent variable.

All data cover the 1989-2012 period and 28 former socialist-block countries identified by the EBRD (672 country-years). In 2001, there were all together 32.2 million women living in the 28 countries. Table A2 in the online appendix provides an overview of the variables used in the cross-country analysis. 


\section{Privatisation and fertility}

\section{Statistical analysis}

Within the study's timeframe of 17 years, the data from the selected 52 towns resulted in 936 observations (town-years) in total. To understand the hierarchical structure of the data and show which variables vary through time and across towns, we computed the intra-class correlation (rho) for every variable used in the models (see the last column in Table A1). A small value of rho means that the correlation of the values for the given variable within towns is low. Thus, a large part of the variation comes from within towns. If the value of the rho is high, it means that a large part of the variance arises between the towns. Variables like the year variable, which differs only across time but not across towns, have a rho of zero. On the contrary, variables such as the percentage of Catholics do not change within towns. Therefore, the rho shows that the variable's values are perfectly correlated within the town (rho=1), and only between-group variance is found.

As a logical corollary of our data structure, the Breusch-Pagan test would show significant heteroscedasticity, and the Wooldridge test would show significant autocorrelation. Thus, the appropriate modeling strategy has to consider the hierarchical nature of the data (Rabe-Hesketh and Skrondal 2012). Although we could obtain data on a significant number of potential confounding variables from the literature, other unobserved time-invariant characteristics could still influence the results. These considerations point towards the need to utilize fixed effects modeling. The Hausman test also showed that fixed effects regression was preferable. Therefore, we fit fixed-effects panel models to estimate the within-town association through time between the dependent and independent variables.

We also analyze the association between fertility and some time-invariant variables in random-effects models to explicitly draw out the effect of relevant factors identified in previous research and to assess whether they suppressed the primary independent variable. The random- 


\section{Privatisation and fertility}

effects models use both variations over time and variation across towns but are sensitive to unobserved heterogeneity. If we find a significant association in the fixed effects models, we do not expect the random effects models to differ. The fixed effects models offer a more stringent test as they, by definition, filter out the influence of unobserved town-level time-invariants. However, the random effects models allow us to test theoretically relevant variables not available in timeseries. Finally, we also test the impact of some potential national-level time-variant processes previously associated with fertility that could bias the fixed-effects models. We also fit fixedeffects models with cluster-robust standard errors for the cross-country analysis on the associationbetween privatization and fertility.

\section{Modeling and variables}

Town-year is the unit of analysis covering 18 years from 1989 to 2006. Town-level privatization (refers to the annual share of private ownership in the largest companies' assets) is the primary independent variable, and the town-level yearly total fertility rate is the dependent variable.

We created a measure of privatization, which is the primary independent variable of our analysis. First, we calculated the proportion of company shares owned by the state and private investors annually for each year between 1989 and 2006. Then, we calculated the average portions of different ownership assets across the five companies in each town annually. This way, we aggregated the company-level data up to the town level and linked privatization to town-level variables of interest. We created annual time series variables for the shares of state ownership and private ownership. Our primary independent variable is town-level privatization, measured as the town-level private ownership share of companies (the values range from 0 to $100 \%$ ). It is reasonable to assume that privatization affects childbirth at least with a nine-month time lag; 


\section{Privatisation and fertility}

therefore, we used a one-year lag for privatization throughout the models. Our dependent variable is town-level total fertility rate, which was available for each year and collected from the HCSO.

We included several control variables to check for potential confounding factors and analyze alternative explanations based on the literature, whether in town-level time series format, town-level variables available for only one year, or in national-level time-series form. We used population size (number of inhabitants) as the primary control variable in every model to filter out the potential effect of urbanization (towns’ population size) on fertility. We put other town-level control variables into seven groups, three with time-variant, and four with time-invariant variables. Then, we built the regression models corresponding to these groups, i.e., three fixed effects, four random-effects models. Finally, a robustness check with macro trends was carried out. Table A1 in the appendix presents an overview of the variables structured accordingly.

The first group of control variables comprises data on basic town-level economic characteristics, i.e., income per capita and unemployment, that were often significant in studies following the economic crisis approach. The second group includes data on essential town-level demographic characteristics, such as child mortality and migration (to filter out the effect of population movement, e.g., lower fertility due to young people leaving). The third group comprises variables on the towns' public services (number of kindergarten places, number of hospital beds, number of primary school teachers). The economic crisis approach has emphasized the role of the welfare state in the fertility decline, and these variables act as proxies for the quality of town-level public services. The hypothesis is that a lower level of public services is associated with lower fertility. However, improved access to health services has also been associated with lower fertility in some countries (Brauner-Otto et al. 2007); therefore, we control for health services, proxied in this study by the number of hospital beds. 


\section{Privatisation and fertility}

The fourth group comprises time-invariant information on the towns' cultural characteristics. The SDT approach emphasizes the role of secularization in the fertility decline, while there is evidence that the Roma population displays higher fertility rates. The fifth group comprises variables on educational attainment among the towns' inhabitants in 2001, derived from the economic opportunity approach. Previous studies have associated the expansion of higher education with a fertility drop (Kohler et al. 2002; Spéder and Bartus 2017), and this is one way of measuring it in this research (to account for the role of education, we also include a measure of annual female tertiary school enrolment as a national-level variable). The sixth group comprises variables on the towns' labor market structure by gender. To control for the potential of increased female employment negatively affecting fertility, we add male and female employment levels and their ratio. The seventh group comprises variables on the towns' economic structure. Based on the SDT approach, we should expect lower fertility in towns with a more modern economic structure (i.e., higher levels of service and industrial employment). ${ }^{12}$

Finally, we also include variables to control for macro trends. Fixed effects regression only filters out time-invariant unobserved heterogeneity but is sensitive to unmeasured time-variant factors. Secular macroeconomic processes that affect every town or gradual cultural changes that occur as the country transitions from socialism to capitalism can interfere with the fixed-effects models. One way to handle this is to include year fixed effects. However, this approach is problematic if we want to measure another variable that expresses change over time with moderate variation across the units, such as privatization. As shown in Table A1, only $11 \%$ of the privatization variable's total variation is between towns (rho=0.112). According to Johnston et al. (2018) as well as Allison (2010), Variance Inflation Factors (VIFs) of 2.5 or greater should be considered indicative of considerable collinearity, which could make it statistically difficult to 


\section{Privatisation and fertility}

separate the independent contribution of variables with such large VIFs. The year dummy variables and the privatization variable show high collinearity, with a Variance Inflation Factor of 3.67. Therefore, including year fixed effects would eliminate a large part of the variation of our primary independent variable by design, thus suppressing the primary association by a statistical artifact. Therefore, we choose a different approach, as explained below.

Firstly, we include a time trend variable and a period dummy into our models. The time trend variable filters out any unobserved linear macro-trends, such as a gradual cultural change, and the period dummy corresponds to the national parliamentary elections held every four years. Secondly, we run separate models with national-level time-series variables derived from the literature. Researchers following the economic crisis approach have demonstrated the critical role of the transformational economic crisis for fertility (Ellman 2000). Therefore, we control for this by including real income growth, the unemployment rate, and the top $1 \%$ share in pre-tax national income. Research has also shown the significance of the eroding welfare state through a real decline in the value of family subsidies; we control for this by including variables for the inflation rate and the welfare state size (using general government final consumption expenditure [GFCE] as a proxy). Finally, proponents of the economic opportunity approach have found a negative association between women’s economic opportunities and fertility (Brewster and Rindfuss 2000). Thus, we include the female to male employment ratio and tertiary female school enrolment rate in separate models.

Following the logic of the town-level models, we fit six models in the cross-country analysis. We use the annual total fertility rate as the dependent variable and the EBRD privatization index as the primary independent variable in each model. Each model controls for the countries’ population size and the time trend. We use the linear time trend variable for the same reason as in 


\section{Privatisation and fertility}

the town-level dataset: high collinearity of the time fixed effects with the privatization variable that mostly only varies within countries (VIF=3.76). The time trend variable filters out gradual global change. The first model only includes the dependent and independent variables (in addition to the population size and the time trend). Model 2 includes control variables for economic processes (total unemployment rate, GDP per capita, government final consumption expenditure, and the consumer price index). Model 3 comprises control variables related to modernization (urbanization, employment in industry, employment in services). Model 4 controls for demographic trends (infant mortality, homicides, net migration). Model 5 controls for healthinfrastructure-related factors (number of hospital beds and physicians). Finally, model 6 includes control variables related to women's opportunity (female tertiary school enrolment rate, female labor force participation rate, female to male labor force participation ratio, female unemployment).

We introduce the control variables in groups to avoid overfitting, i.e., to keep multicollinearity low with a VIF below 2.5 for the primary independent variable (privatization). We use cluster-robust standard errors to adjust for heteroscedasticity and autocorrelation and carry out all statistical analyses using STATA 13.0 (StataCorp, Texas, USA).

\section{Results}

\section{Privatization and fertility}

Figure 3 here

Figure 3 presents an overview of the mean fertility and privatization trends in the 52 towns. Changes in fertility and privatization closely followed each other, suggesting a robust correlation $(\mathrm{r}=-0.937)$. Privatization was most rapid before 1996, when fertility dropped the most. 


\section{Privatisation and fertility}

Privatization slowed down in the second half of the 1990s, with the fertility drop also abating. Finally, as privatization came to a halt during the 2000s, fertility stopped declining further.

Table 1 presents an overview of the main results of fixed-effects models of the association between privatization and town-level fertility. In model 1, we found that full-scale privatization of company assets (that is, a transition from zero to $100 \%$ private ownership) is associated with 0.7 fewer children for a hypothetical woman throughout her childbearing years controlling for towns’ population size $(\mathrm{b}=-0.007, \mathrm{p}<0.001){ }^{13}$

Table 1 here

The association holds after controlling for town-level income per capita and unemployment in model 2 ( $b=-0.005, \mathrm{p}<0.001)$. Consistent with wider demographic research, we found a negative association between income per capita and fertility, indicating that fertility declines as income grows. The town-level unemployment rate positively correlates with fertility, predicting 0.083 more children as unemployment increases by ten percentage points.

Demographic factors — infant mortality, in-migration, out-migration — in model 3 are not associated with fertility, while the privatization variable remains significant $(b=-0.005, p<0.001)$. The number of hospital beds predicts higher fertility. Adding one hospital bed per 1000 inhabitants predicts 0.018 more children per woman, but this only slightly suppresses the privatization variable, which remains significant ( $b=-0.0043, \mathrm{p}<0.001$ ). Finally, in model 5, we included every control variable simultaneously - at the risk of model-overfitting. The privatization variable's strength is attenuated, but it remains significant in this specification ( $b=-0.0042, p<0.001)$.

To put the magnitude of these findings in perspective, average fertility declined by 0.68 points from 1.98 in 1990 to 1.30 in 2006 in the sampled towns. Full-scale privatization from zero to $100 \%$ private ownership could account for 0.41 points ( $60 \%$ of the total fertility decline) based 


\section{Privatisation and fertility}

on the fully adjusted model 6 , Table 2 . The median value of private ownership in the 52 towns in 1989 was zero, and $98.2 \%$ in 2006 ; the mean was $90 \%$ in the same year. The observed averagelevel of privatization could explain $54.3 \%$ of the average fertility decline ( 0.37 fewer children per woman), filtering out other relevant economic, demographic, health-related, and infrastructural characteristics of the towns as well as time-invariant unobserved heterogeneity.

To assess the influence of alternative mechanisms on the association between privatization and fertility, we fitted separate random effects models, as presented in Table A3 of the appendix. Privatization remains significantly associated with fertility in every model $(-0.0049 \leq b \leq-0.0048$, $\mathrm{p}<0.001)$. Income and unemployment behave in the same way as in the fixed effects regressions. A $10 \%$ increase in the Roma population is associated with 0.3 more children per woman. The towns' cross-sectional differences in composition by education are also not associated with fertility (the next section presents a more robust analysis of the association between the expansion of higher education and fertility).

We analyzed the association between privatization and gender-specific employment rates in more detail. We divided towns into private ownership-dominated and state ownershipdominated categories. ${ }^{14}$ As Table 2 shows, towns that were dominated by state ownership between 1989 and 2006 had, on average, five percentage points higher female to male employment ratios in 1990, and the gap grew slightly to 6 percentage points in 2001. In 2001, the female to male employment ratio in state-ownership-dominated towns was $90 \%$, suggesting that relatively more women remained employed in towns with less privatization. Even if we disregard the intensity of the change and the question of causality, it is clear that towns with less privatization exhibit a higher female to male employment ratio.

Table 2 here 


\section{Privatisation and fertility}

\section{Controlling for macro trends}

We tested the robustness of the privatization variable's effect in the presence of global and national-level time-variant factors. Table A4 in the appendix shows the results of the fixed effects regressions with an annual trend variable (year) included. Again, every model is adjusted for population size, and privatization is lagged one year. The association between privatization and fertility remains significant in all models $(-0.0032 \leq \mathrm{b} \leq-0.0018, \mathrm{p}<0.01)$. The inclusion of a linear time trend reduces the association's strength, as the time trend variable is highly significant and negative and correlates with the income variable. Income, unemployment, in-migration, and the number of primary school teachers proved to be significant control variables.

Next, we specified a model to filter out period change by including time fixed effects dummies representing the four-year periods. This approach captures government change (as elections take place every four years), as well as slow-changing non-linear macro factors, such as slow-paced cultural change. As shown in Table 3, privatization remains significantly associated with fertility $(-0.0022 \leq \mathrm{b} \leq-0.0019, \mathrm{p}<0.01)$, with somewhat reduced strength. The period dummies, income, and in-migration were significant control variables.

Table 3 here

Finally, we directly tested the impact of theoretically relevant national-level processes on the association between privatization and fertility. ${ }^{15}$ As shown in Table 4, introducing these macrolevel variables into our models did not substantially change the results. The association between privatization and fertility remains significant in every model $(-0.006 \leq \mathrm{b} \leq-0.002, \mathrm{p}<0.01)$. All macro-level variables are significant, but without suppressing the effect of privatization. Including female to male employment ratio in model 7 reduces the privatization variable's strength the most, followed by income inequality. 


\section{Privatisation and fertility}

Table 4 here

Income and unemployment behave in the same way as in the previous models. The association between the increase in inequality and fertility is negative: A $1 \%$ increase in the top $1 \%$ income predicts a 0.12 -point decline in fertility. Simultaneously, a $1 \%$ increase in government spending is associated with 0.04 points higher fertility. The association between inflation and fertility is positive, which is a counterintuitive result. Importantly, we also tested the effect of the expansion of higher education on fertility. The increase in the female tertiary school enrolment rate is associated with lower fertility, as the literature suggests; a $10 \%$ increase in the female tertiary enrollment ratio is associated with a 0.054 decline in the fertility rate. The association between national-level female to male employment ratio and fertility is positive, i.e., a 1\% decline in female to male employment ratio correlates with 0.02 fewer children per woman.

\section{Cross-country analysis}

As described in the methods section, we created a separate cross-country dataset with country-level time-series information, following the town-level analysis’s logic. Figure 4 presents an overview of the mean fertility and privatization trends in the 28 countries. Confirming the town-

level association, fertility and privatization changes followed each other closely, suggesting again a very strong correlation ( $\mathrm{r}=-0.955)$.

\section{Figure 4 here}

Figure 5 presents a graphic overview of the cross-country results. The $\mathrm{X}$-axis presents the value of the regression coefficients (b) sorted by size, while the Y-axis presents the models, concentrating on the privatization variable, and the size of the boxes represents $95 \%$ confidence intervals, with the value of the coefficient indicated at the center. Table A5 in the appendix presents the cross-country model results in more detail using a regression table. ${ }^{16}$ 


\section{Privatisation and fertility}

\section{Figure 5 here}

As Figure 5 shows, privatization is robustly negatively associated with fertility in each model $(-0.239 \leq \mathrm{b} \leq-0.159 ; \mathrm{p}<0.001)$. A 1 -point increase in the value of the EBRD privatization index is associated with at least a 0.16-point decrease in the total fertility rate, net of other factors, also filtering out unobserved country-level time-invariant characteristics as well as unobserved global trends. Consistent with the extant demographic research, we found that government consumption, the consumer price index, GDP per capita, female/male employment ratio, female labor force participation, and physicians' number are significantly associated with fertility. However, none of these variables reduces the privatization variable's significance, though the association's strength is attenuated.

To compare the magnitude of these findings, average fertility declined by 0.68 points from 2.58 in 1989 to 1.84 in 2012 across the 28 countries in postsocialist Eastern Europe. In parallel, the privatization index increased from 1.23 in 1989 to 3.54 in 2012 . Based on the regression coefficient estimated by controlling for each significant confounder in the cross-country fixed effects models, the observed average level of privatization across the 28 countries could explain 49.75\% of the total fertility decline ( 0.37 fewer children per woman).

The geographic clustering of political, demographic, and cultural factors might influence the privatization-fertility mechanism. There might be differences between former members of the Soviet Union (FSU) and other postsocialist countries that retained their statehood. Countries in Asia and Europe might also differ, as socialist countries in Asia had higher fertility rates and progressed with privatization more slowly than countries in East-Central Europe. We tested these geographical differences by splitting the sample, as shown in Tables A6-A9 in the appendix. The privatization variable appears to be stronger and more robust in FSU countries (Table A7) and 


\section{Privatisation and fertility}

European countries (Table A8). While the privatization variable remains significant in the sample that excludes FSU countries, it loses its significance in some of the models run on the Asian sample.

\section{Discussion}

In this study, we tested the effect of privatization on fertility across medium-sized towns in Hungary and cross-nationally across postsocialist countries. Our main models suggest that the observed average-level of privatization could explain half of the average fertility decline in the 52 Hungarian towns and 28 postsocialist countries. Companies played an even more critical role in providing welfare services in the former Soviet republics and in countries located in Europe, as shown by the split-sample results. Even after controlling for crucial national-level time-variant processes — including government spending and the expansion of female school enrolment —, we found that privatization could account for at least 32\% of the overall fertility decline. However, since many of these macro-processes correlate strongly with privatization, we believe this is a conservative estimate. The association is robust to including a battery of town- and national-level control variables derived from the fertility literature. We also found that fertility appears to be higher in towns with less privatization despite higher female employment in state-ownership dominated towns. ${ }^{17}$

We extend the extant literature by a new theoretical framework linking privatization to fertility. State-owned socialist companies were institutional mechanisms of decommodification. Although socialist companies were not efficient from a profit-making perspective (Kornai 1980), they were better at performing social functions through the fringe benefits they provided. Through these functions, socialist companies increased the social "capacities available to create and maintain social bonds, which includes the work of socializing the young, building communities, 


\section{Privatisation and fertility}

reproducing the shared meanings, affective dispositions and horizons of value” (Fraser 2014:542). Socialist companies contributed to higher female labor force participation rates while also providing a more favorable environment for having children.

The privatization of state-owned companies increases uncertainty (financial and temporal uncertainty), which might decrease families' willingness to make long term commitments. Privatization also leads to a loss of direct collective resources (food, childcare, ability to return to work after childbearing), which may shift care work costs onto families. Finally, privatization might diminish indirect collective resources pertinent for social reproduction, such as housing, holiday, cultural, and sports services, as well as communities (i.e., social capital), which decreases the resources available for social reproduction. Through these mechanisms, privatization might lead to fertility decline. Once privatization ends, fertility stabilizes at a lower rate until new institutional support mechanisms are introduced to ease the tension between economic production and social reproduction.

Our results also fit well with Fodor's (2003) findings, who showed that, before the transition, Hungarian managerial women were more likely to have children than Austrian ones because they had access to both company and government welfare arrangements. Philipov et al. (2006) also reported similar findings from Bulgaria, showing that women working in state-owned firms are more likely than women in other labor-market groups to intend to have a child earlier. Our work echoes the findings of the institutionalist scholarship on the postsocialist transformation on the role of the state in preserving and restructuring socialist companies as opposed to rapid privatization (Hamm et al. 2012) and on the negative effect of welfare state retrenchment on family formation (Fodor 2004; Haney 2002). Our study also adds to the emerging discussion that has started to re-evaluate post-socialist privatization from the perspective of its contribution to 


\section{Privatisation and fertility}

increasing income inequality (Bandelj and Mahutga 2010; Fodor and Horn 2015; Jackson and Evans 2017; Mahutga and Jorgenson 2016) and mortality differentials (Scheiring et al. 2018; Stuckler et al. 2009).

Privatization is not the only upstream factor influencing fertility. As suggested by the economic opportunity approach, we found that a higher level of female labor force participation is associated with lower fertility measured at towns' level. However, the association between the national-level female to male employment ratio and fertility is positive. Therefore, the evidence on the association between women's employment and fertility is contradictory. Furthermore, we also found that towns with a higher level of privatization had lower fertility despite having significantly lower female employment, which contradicts the economic opportunity approach, and is in accordance with studies that show that there is no necessary conflict between female employment and fertility.

Women's opportunity indicators are also ambivalent in the cross-country analysis. A higher female labor force participation is associated with higher fertility, reflecting cross-country results presented by Rindfuss et al. (2003). This association could again show that socialist welfare arrangements helped ease the burden of having children and allowed more women to work without depressing fertility. On the other hand, a higher female to male employment ratio correlates with lower fertility in the cross-country analysis. This correlation could reflect several things. Male employment rates declined more during the transition, which increased the female to male employment ratio over time. The loss of men’s stable jobs could have depressed fertility, picked up by the female to male employment ratio. Another potential explanation is that the socialist welfare arrangements eroded with time, making women's employment less compatible with having children. 


\section{Privatisation and fertility}

Our results have also confirmed some of the arguments proposed by scholars following the economic crisis approach. We found a strong association between income inequality and having children, in line with the findings from the US (Cherlin et al. 2016). However, the association between inequality and fertility is complex, as higher inequality might also lead to more teen pregnancies (Gold et al. 2002), suggesting that different age groups and income categories might react differently to income inequality. We also found signs that public services, such as local health-care infrastructure and the number of primary school teachers, as well as national welfare state provision, might act as buffers against declining fertility. However, we did not test the association between public services and fertility in detail, leaving the direction of the association and the question of causality open. Declining fertility might lead to lower welfare provision and a decline in school teachers. Nevertheless, leaving these questions open does not influence the main association between privatization and fertility.

Contradicting the economic crisis approach, we have found evidence that, in the long run, the growth of incomes contributes to the fertility decline as suggested by the SDT approach (Bollen et al. 2007; Lesthaeghe and Surkyn 2002; Sobotka 2003). The role of unemployment is also ambiguous. Individual unemployment might reduce the likelihood of having children (Kreyenfeld 2010), but our data suggest that contextual unemployment is associated with higher fertility, echoing the results of Kohler and Kohler (2002).

We also found evidence underpinning the SDT approach. A larger share of service sector employment appears to correlate strongly with lower fertility compared to agriculture. This crosssectional correlation might be interpreted as a sign of economic modernization leading to cultural change. The available data are not suitable to further investigate the temporal dimension of the economic modernization effect. In other contexts, the association between service-sector 


\section{Privatisation and fertility}

employment and fertility might be different. Scandinavia and the Netherlands both have experienced fertility recovery in tandem with service economy growth. Future research should specify the effect of service sector growth in the early and late stages of modernization, in the presence of welfare state arrangements, and the composition of the service economy.

Although we noticed a weak positive correlation between the share of Calvinists and fertility, religious factors appear to be less relevant. On the contrary, the positive association between a higher percentage of the Roma population and more children is robust. We also found evidence that the increase in women's participation in higher education contributes to lower fertility. Again, the association's direction is an open question; declining fertility could also allow more women to obtain a college degree. However, the bottom line is that higher education expansion does not influence the privatization-fertility link.

\section{Limitations}

Our study has some limitations. First, the total fertility rate is not an ideal outcome variable to measure fertility changes. The postponement of childbearing leads to a rising mean age at birth and also to a decrease in the observed period age-specific fertility rates, as births are spread out over a more extended period (Philipov and Kohler 2001). As the final number of children could approach the intended number of children by the end of the reproductive age span, period TFR could overestimate the actual decline in fertility (Balbo et al. 2013; Spéder and Kapitány 2009). As postponement behavior stops, fertility could rise again. In recent years, Hungary has indeed seen an increase in the TFR. However, it is unclear if this reflects a fundamental shift in the number of children families have or rather the expression of the decreasing number of women of childbearing age, which increases TFR despite the fewer births in total (Kapitány and Spéder 2018). Despite its limitations, TFR is still frequently used because of its wide availability and some 


\section{Privatisation and fertility}

of its advantages (Aksoy and Billari 2018; Hendi 2017). TFR has an intuitive interpretation, and it is age-standardized. Furthermore, the timing of fertility — the postponement of earlier births — also influences children's overall number. However, further research is necessary to ascertain the details of the privatization-fertility mechanism, separating tempo and quantum effects by adjusting the total fertility rate, and paying more attention to parity progression.

Second, using town- and country-level data leaves a potential for ecological fallacy because individuals are omitted from the analysis. However, town- and country-level data also have advantages. Most importantly, it allows us to link privatization to fertility, which would not be feasible relying only on individual surveys. Besides, the availability of demographic and socioeconomic variables at the contextual level allows us to control for factors identified in the literature as relevant for fertility. Future research should combine contextual-level determinants with individual-level data.

Third, the towns involved in the analysis might differ across other unobservable characteristics. We tackled this limitation by fitting fixed effects panel models that, by definition, filter out unobserved time-invariant heterogeneity. However, time-variant characteristics of the towns might still play a role. We controlled for the most critical national macro-trends identified in the literature, such as inflation, income inequality, welfare state spending, growth, unemployment, female tertiary school enrolment, and the female to male employment ratio as well as other unobserved macro-trends - both in the town-level and the country-level analyzes. We believe that there remains only minimal potential for a theoretically relevant unobserved background factor that could have influenced both the privatization and the fertility variable. However, observational data have their limitations, and we should be cautious when formulating causal conclusions. 


\section{Privatisation and fertility}

Fourth, our research design does not entirely preclude the potential for selection bias. Theoretically, it could be possible that collapsing companies were privatized more quickly and that these companies’ bad performance also negatively impacted their workforce, which in turn could have depressed fertility. Negative expectations based on past economic performance might have induced people to postpone having children and prompted decision makers to privatize more quickly to improve the economy. However, we believe that the distribution of privatization across towns is close to random, approximating a natural experiment. The existing literature has shown that privatization was a political decision (Hamm et al. 2012), and we have no reason to believe that the decision to privatize could have been influenced by the towns' (or countries') demographic characteristics. Hamm et al. (2012) also highlighted that there is minimal potential that towns (countries) with a higher propensity for fertility decline selected into faster privatization programs.

Some sectoral-level analyses show that more profitable companies were privatized first, while the privatization of more problematic companies was delayed (Gupta et al. 2008; King 2000). If company profitability translates into higher social welfare, which translates into greater security and higher fertility, this could imply a selection bias where towns (countries) with less propensity for fertility decline could have selected themselves into faster privatization. In short, if there is a selection bias, it probably makes our models more conservative, as the logic most likely works against the central hypothesis. In short, we see minimal potential for selection bias that could invalidate our findings; nevertheless, we must undoubtedly caution against interpreting the results as causal associations.

Fifth, our main sample is restricted to medium-sized towns. Smaller towns and villages experienced a different shock related to the collapse of agriculture. We do not see much theoretical reason to believe that privatization had a different impact on towns in different size categories. We 


\section{Privatisation and fertility}

also filtered out the role of the town's population size in every regression model. Privatization might have effects that can only be measured at the national level: Private investors might contribute to economic activity, export performance, or productivity improvements, which might generate welfare benefits outside the towns. Our modeling approach took care of some of these issues, but national-level processes outside the 52 towns might complicate the picture. We also fitted cross-country fixed-effects models, which confirmed the town-level models.

Finally, our data on privatization only cover the five largest companies. Small firms could replace the activity of big state-owned enterprises. However, due to the data limitations discussed, it would be very time- and resource-consuming to design a more robust approach than the one used in this paper. Although the cross-country models confirmed the town-level regressions, suggesting that the selection of the five largest companies is a viable strategy, future research should combine more robust national- and regional-level data on privatization to better assess its demographic effects.

\section{Conclusions}

Privatization could have been a crucial, so far neglected factor behind the unprecedented fertility decline. It is most likely that the postsocialist fertility decline cannot be reduced to a single causal mechanism, with the economic crisis, economic opportunities, anomie, and postmodernization all playing a role. However, paying more attention to state-owned companies’ decommodification functions and the consequences of their privatization can improve research on fertility.

This theoretical lesson also has implications for policy and politics. The population decline in Eastern Europe has engendered the rise of "demographic nationalism” and various new pronatalist policies that are not rooted in evidence-based research (Melegh 2016) and fail to address 
the contextual factors contributing to low fertility. Nativism, populism, gender, and the politics of reproduction are becoming intertwined in an increasing number of countries (Franklin and Ginsburg 2019). Thus, a better understanding of the role of company-privatization in fertility change might contribute to not only better policies but also more inclusive politics. Policies only focusing on individual incentives neglecting the contextual factors are insufficient to ease the tension between economic production and social reproduction. Female employment and women's economic opportunities are not in contradiction with higher fertility if the institutional context helps mitigate uncertainties, socialize the costs of social reproduction, and provide other resources that can be indirectly used to aid raising children. 


\section{Privatisation and fertility}

\section{Notes}

${ }^{1}$ The total fertility rate (TFR), sometimes also called period total fertility rate, is the average number of children that would be born to a woman over her lifetime according to current age-specific fertility rates.

${ }^{2}$ Based on the Cambridge Dictionary, by privatization we mean "the act of selling an industry, company or service that was owned and controlled by the government, so it becomes privately owned and controlled.” However, as Savas (2000) has also highlighted, privatization does not necessarily entail the selling of company assets, and might involve other forms of private sector involvement (outsourcing, concessions, etc.) that also introduce private, competitive, market-based logics. Thus, our conservative approach to privatization captures only a subset of a broader set of cases representing a move towards commodification.

${ }^{3}$ A high gross enrolment ratio may reflect a relatively high number of overage children enrolled in each grade because of repetition or late entry. According to the UNESCO definition, also used by the World Bank, gross tertiary enrolment is "the total enrolment in tertiary education regardless of age expressed as a percentage of the population in the 5-year age group immediately following upper secondary education.” Source: http://uis.unesco.org/en/glossary-term/grossenrolment-ratio-tertiary-education

${ }^{4}$ The socialist state introduced generous family support systems that eased the tension between childbearing and women's employment. The state offered a lump sum of universally available family allowance, a flat childcare allowance (GYES), a wage-related parental-leave benefit (GYED) that provided 75\% of the previous income for up to 2 years, and an extended network of childcare institutions. Although governments emphasized different elements of the system conservative governments encouraged childbearing in the upper-middle class while left-liberal governments put more emphasis on social policy —, the policies introduced under state socialism have represented the gist of family policy ever since.

${ }^{5}$ King et al. (2006:33) hypothesized that "since the mortality effects of privatization are only prominent among men, fertility is absorbing some of the effects of psychosocial stress [among women]."

${ }^{6}$ We use the term "social reproduction" as it is used in feminist political economy, referring to the role of households, families and women as child-bearers and family care-takers to produce and maintain current and future workers, which represents an unacknowledged contribution to the capitalist economy. This usage differs from how the term is used in Bourdieusian literature, which refers to the emphasis on the structures and activities that transmit social inequality from one generation to the next.

${ }^{7}$ A detailed discussion of "the company-based welfare state" is presented by Schmidt and Ritter (2013:47-50).

${ }^{8}$ Mills and Blossfeld (2005) talk about three forms but we find that two basic types are sufficient to capture the experience of uncertainty.

${ }^{9}$ We have no reasons to believe that the trends that started to unfold after 2006 were latently present already before 2006. The economy was growing strongly until 2006, EU accession euphoria also lasted a few years after the actual accession in 2004, most social indicators were improving. The real upheaval began after 2006, when Hungary’s development model and the underlying social contract entered into a deep crisis. This manifested in a deep fall in trust in politics, rapid loss of popularity of the governing Socialist Party, declining state revenues and recurrent waves of austerity measures. The crisis of the postsocialist development model gave way to the birth of Viktor Orbán’s regime, which represents a significant change also in the dimension of family policies (Scheiring and Szombati 2020).

10 The company database of the Institute of Economics at the Hungarian Academy of Sciences contains useful information on company ownership and performance but misses crucial years in the early 1990s and makes it impossible to link parent and successor companies, which is important as many companies were completely restructured by creating new legal entities during the early years of the postsocialist transition.

${ }^{11}$ One town out of the 52 changed its name in 1992, as one of its districts became an autonomous township. Thus, some of the demographic variables for this town are missing for 1990 and 1991.

${ }^{12}$ Though, in other contexts, such as other stages of modernization, or in the presence of robust welfare states, the association might be different, as we elaborate in the discussion section.

${ }^{13}$ Most state-owned companies started with zero private ownership and ended up in full private control.

${ }^{14}$ Unfortunately, we did not have enough data on employment to run robust separate regressions.

${ }^{15}$ We do not present a fully controlled model because of high multicollinearity between the national-level trend variables.

${ }^{16}$ We do not present a fully controlled model because of high multicollinearity between the covariates.

17 The state possibly remained a dominant owner in companies that already had a high proportion of female employees in the workforce, such as the textiles and clothing industry. 


\section{Tables and figures}

Table 1. Privatization and fertility 1989-2006, town-level fixed effects models

\begin{tabular}{|c|c|c|c|c|c|}
\hline & $(1)$ & $(2)$ & (3) & (4) & $(5)$ \\
\hline & $\mathrm{b} / \mathrm{se}$ & $\mathrm{b} / \mathrm{se}$ & $\mathrm{b} / \mathrm{se}$ & $\mathrm{b} / \mathrm{se}$ & $\mathrm{b} / \mathrm{se}$ \\
\hline Privatization \% (0-100) & $\begin{array}{l}-0.0070 * * * \\
(0.00)\end{array}$ & $\begin{array}{l}-0.0052^{* * *} \\
(0.00)\end{array}$ & $\begin{array}{l}-0.0050^{* * *} \\
(0.00)\end{array}$ & $\begin{array}{l}-0.0043^{* * *} \\
(0.00)\end{array}$ & $\begin{array}{l}-0.0042^{* * *} \\
(0.00)\end{array}$ \\
\hline Income per capita (10000 HUF) & & $\begin{array}{l}-0.0047 * * * \\
(0.00)\end{array}$ & $\begin{array}{l}-0.0058^{* * *} \\
(0.00)\end{array}$ & $\begin{array}{l}-0.0059^{* * *} \\
(0.00)\end{array}$ & $\begin{array}{l}-0.0063^{* * *} \\
(0.00)\end{array}$ \\
\hline Unemployment & & $\begin{array}{l}0.0083 * \\
(0.00)\end{array}$ & $\begin{array}{l}0.0088 * \\
(0.00)\end{array}$ & $\begin{array}{l}0.0066 \\
(0.00)\end{array}$ & $\begin{array}{l}0.0085^{*} \\
(0.00)\end{array}$ \\
\hline Infant mortality per 1000 inhabitant & & & $\begin{array}{l}-0.0007 \\
(0.00)\end{array}$ & & $\begin{array}{l}-0.0017 \\
(0.00)\end{array}$ \\
\hline In-migration per 1000 inhabitant & & & $\begin{array}{l}0.0035 \\
(0.00)\end{array}$ & & $\begin{array}{l}0.0021 \\
(0.00)\end{array}$ \\
\hline Out-migration per 1000 inhabitant & & & $\begin{array}{l}0.0046 \\
(0.00)\end{array}$ & & $\begin{array}{l}0.0040 \\
(0.00)\end{array}$ \\
\hline Kindergarten places per 1000 inhabitant & & & & $\begin{array}{l}0.0127 \\
(0.01)\end{array}$ & $\begin{array}{l}0.0109 \\
(0.01)\end{array}$ \\
\hline No of hospital beds per 1000 inhabitant & & & & $\begin{array}{l}0.0176^{* *} \\
(0.01)\end{array}$ & $\begin{array}{l}0.0165^{*} \\
(0.01)\end{array}$ \\
\hline Primary school teachers per 1000 inhabitant & & & & $\begin{array}{l}0.0138 \\
(0.01)\end{array}$ & $\begin{array}{l}0.0144 \\
(0.01)\end{array}$ \\
\hline Constant & $\begin{array}{l}1.1311^{* *} \\
(0.38)\end{array}$ & $\begin{array}{l}1.8981^{* * *} \\
(0.44)\end{array}$ & $\begin{array}{l}1.9975^{* * *} \\
(0.32)\end{array}$ & $\begin{array}{l}2.0073^{* * *} \\
(0.36)\end{array}$ & $\begin{array}{l}1.6969 * * * \\
(0.39)\end{array}$ \\
\hline No. of observations[town-years] & 935 & 934 & 933 & 822 & 822 \\
\hline No. of groups[towns] & 52 & 52 & 52 & 52 & 52 \\
\hline
\end{tabular}

${ }^{*} \mathrm{p}<0.05, * * \mathrm{p}<0.01, * * * \mathrm{p}<0.001$

Note:

Dependent variable: total fertility rate. Privatization is lagged one year.

All models are adjusted for annual population size.

Cluster-robust standard errors are in parentheses. 
Table 2. Privatization and female to male employment rate ratio, town-level

Mean female to male employment ratio

State ownership dominated $(\mathrm{N}=7)$

\begin{tabular}{lll}
1990 & 2001 & $\Delta$ \\
\hline 0.84 & 0.90 & +0.06 \\
0.79 & 0.84 & +0.05
\end{tabular}

Private ownership dominated $(\mathrm{N}=45)$

0.79

If the average ownership shares of private owners between 1989 and 2006 exceed that of the state, then we classified the town as dominated by private ownership; if average state ownership exceeds average private ownership, then we classified the town as dominated by state ownership. 
Table 3. Privatization and fertility 1989-2006, town-level fixed effects models plus periods

\begin{tabular}{|c|c|c|c|c|c|}
\hline & $(1)$ & $(2)$ & (3) & (4) & $(5)$ \\
\hline & $\mathrm{b} / \mathrm{se}$ & $\mathrm{b} / \mathrm{se}$ & $\mathrm{b} / \mathrm{se}$ & $\mathrm{b} / \mathrm{se}$ & $\mathrm{b} / \mathrm{se}$ \\
\hline \multirow[t]{2}{*}{ Privatization \% (0-100) } & $-0.0022 * *$ & $-0.0021 * *$ & $-0.0019 * *$ & $-0.0022 * *$ & $-0.0019 * *$ \\
\hline & $(0.00)$ & $(0.00)$ & $(0.00)$ & $(0.00)$ & $(0.00)$ \\
\hline \multirow[t]{2}{*}{ 1995-1998 } & $-0.2768 * * *$ & $-0.2641^{* * *}$ & $-0.2920 * * *$ & $-0.2453^{* * *}$ & $-0.2696 * * *$ \\
\hline & $(0.04)$ & $(0.04)$ & $(0.04)$ & $(0.04)$ & $(0.04)$ \\
\hline \multirow[t]{2}{*}{ 1999-2002 } & $-0.4069 * * *$ & $-0.3504^{* * *}$ & $-0.3590 * * *$ & $-0.3301^{* * *}$ & $-0.3323 * * *$ \\
\hline & $(0.05)$ & $(0.05)$ & $(0.05)$ & $(0.05)$ & $(0.05)$ \\
\hline \multirow[t]{2}{*}{ 2003-2006 } & $-0.4676 * * *$ & $-0.3617 * * *$ & $-0.3945 * * *$ & $-0.3331 * * *$ & $-0.3597 * * *$ \\
\hline & $(0.05)$ & $(0.06)$ & $(0.06)$ & $(0.06)$ & $(0.06)$ \\
\hline \multirow[t]{2}{*}{ Unemployment } & & 0.0011 & 0.0021 & -0.0002 & 0.0028 \\
\hline & & $(0.00)$ & $(0.00)$ & $(0.00)$ & $(0.00)$ \\
\hline \multirow[t]{2}{*}{ Income per capita (10000 HUF) } & & $-0.0028^{* *}$ & $-0.0033^{* *}$ & $-0.0035^{* *}$ & $-0.0038^{* *}$ \\
\hline & & $(0.00)$ & $(0.00)$ & $(0.00)$ & $(0.00)$ \\
\hline \multirow[t]{2}{*}{ Infant mortality per 1000 inhabitant } & & & 0.0005 & & 0.0005 \\
\hline & & & $(0.00)$ & & $(0.00)$ \\
\hline \multirow[t]{2}{*}{ In-migration per 1000 inhabitant } & & & $0.0042 *$ & & 0.0036 \\
\hline & & & $(0.00)$ & & $(0.00)$ \\
\hline \multirow[t]{2}{*}{ Out-migration per 1000 inhabitant } & & & 0.0042 & & 0.0048 \\
\hline & & & $(0.00)$ & & $(0.00)$ \\
\hline \multirow[t]{2}{*}{ Kindergarten places per 1000 inhabitant } & & & & 0.0010 & -0.0019 \\
\hline & & & & $(0.01)$ & $(0.01)$ \\
\hline \multirow[t]{2}{*}{ No of hospital beds per 1000 inhabitant } & & & & 0.0110 & 0.0095 \\
\hline & & & & $(0.01)$ & $(0.01)$ \\
\hline \multirow[t]{2}{*}{ Primary school teachers per 1000 inhabitant } & & & & 0.0083 & 0.0068 \\
\hline & & & & $(0.01)$ & $(0.01)$ \\
\hline \multirow[t]{2}{*}{ Constant } & $1.5656^{* *}$ & $1.9335^{* * *}$ & $2.1201^{* * *}$ & $2.3169 * * *$ & $1.9680 * * *$ \\
\hline & $(0.51)$ & $(0.49)$ & $(0.26)$ & $(0.31)$ & $(0.31)$ \\
\hline No. of observations[town-years] & 935 & 934 & 933 & 822 & 822 \\
\hline No. of groups[towns] & 52 & 52 & 52 & 52 & 52 \\
\hline
\end{tabular}

$* \mathrm{p}<0.05, * * \mathrm{p}<0.01, * * * \mathrm{p}<0.001$

Note:

Dependent variable: total fertility rate. Privatization is lagged one year.

All models are adjusted for annual population size. Cluster-robust standard errors are in parentheses. 
Table 4. Privatization and fertility 1989-2006, town-level fixed effects models plus macro change

\begin{tabular}{|c|c|c|c|c|c|c|c|}
\hline & $(1)$ & $(2)$ & $(3)$ & $(4)$ & $(5)$ & $(6)$ & $(7)$ \\
\hline & $\mathrm{b} / \mathrm{se}$ & $\mathrm{b} / \mathrm{se}$ & $\mathrm{b} / \mathrm{se}$ & $\mathrm{b} / \mathrm{se}$ & $\mathrm{b} / \mathrm{se}$ & $\mathrm{b} / \mathrm{se}$ & $\mathrm{b} / \mathrm{se}$ \\
\hline Privatization \% (0-100) & $\begin{array}{l}-0.0044^{* * *} \\
(0.00)\end{array}$ & $\begin{array}{l}-0.0061^{* * *} \\
(0.00)\end{array}$ & $\begin{array}{l}-0.0020^{* * *} \\
(0.00)\end{array}$ & $\begin{array}{l}-0.0045^{* * *} \\
(0.00)\end{array}$ & $\begin{array}{l}-0.0032^{* * *} \\
(0.00)\end{array}$ & $\begin{array}{l}-0.0042^{* * *} \\
(0.00)\end{array}$ & $\begin{array}{l}-0.0036^{* * *} \\
(0.00)\end{array}$ \\
\hline National real income growth \% & $\begin{array}{l}-0.0240 * * * \\
(0.00)\end{array}$ & & & & & & \\
\hline National unemployment rate \% & & $\begin{array}{l}0.0249 * * * \\
(0.01)\end{array}$ & & & & & \\
\hline Top 1\% share in pre-tax national income (\%) & & & $\begin{array}{l}-0.1237^{* * *} \\
(0.01)\end{array}$ & & & & \\
\hline Government consumption (\% of GDP) & & & & $\begin{array}{l}0.0383^{* * *} \\
(0.01)\end{array}$ & & & \\
\hline National inflation rate & & & & & $\begin{array}{l}0.0151^{* * *} \\
(0.00)\end{array}$ & & \\
\hline School enrollment, tertiary, female (\% gross) & & & & & & $\begin{array}{l}-0.0054^{* * *} \\
(0.00)\end{array}$ & \\
\hline National female to male employment ratio (\%) & & & & & & & $\begin{array}{l}0.0222 * * * \\
(0.00)\end{array}$ \\
\hline Constant & $\begin{array}{l}3.8323^{* * *} \\
(0.52)\end{array}$ & $\begin{array}{l}0.8768 * * \\
(0.33)\end{array}$ & $\begin{array}{l}2.5011^{* * *} \\
(0.40)\end{array}$ & $\begin{array}{l}0.5923 \\
(0.37)\end{array}$ & $\begin{array}{l}-0.5835 \\
(0.31)\end{array}$ & $\begin{array}{l}1.3915^{* * *} \\
(0.32)\end{array}$ & $\begin{array}{l}-0.6512 \\
(0.57)\end{array}$ \\
\hline No. of observations[town-years] & 771 & 822 & 720 & 771 & 822 & 822 & 822 \\
\hline No. of groups[towns] & 52 & 52 & 52 & 52 & 52 & 52 & 52 \\
\hline
\end{tabular}

$* \mathrm{p}<0.05, * * \mathrm{p}<0.01, * * * \mathrm{p}<0.001$

Note:

Dependent variable: total fertility rate. Privatization is lagged one year.

All models are adjusted for annual population size. Cluster-robust standard errors are in parentheses.

All models are adjusted for towns' annual population size, unemployment, in-migration, out-migration. 
Figure 1. The national-level drop in fertility in Hungary, 1980-2009

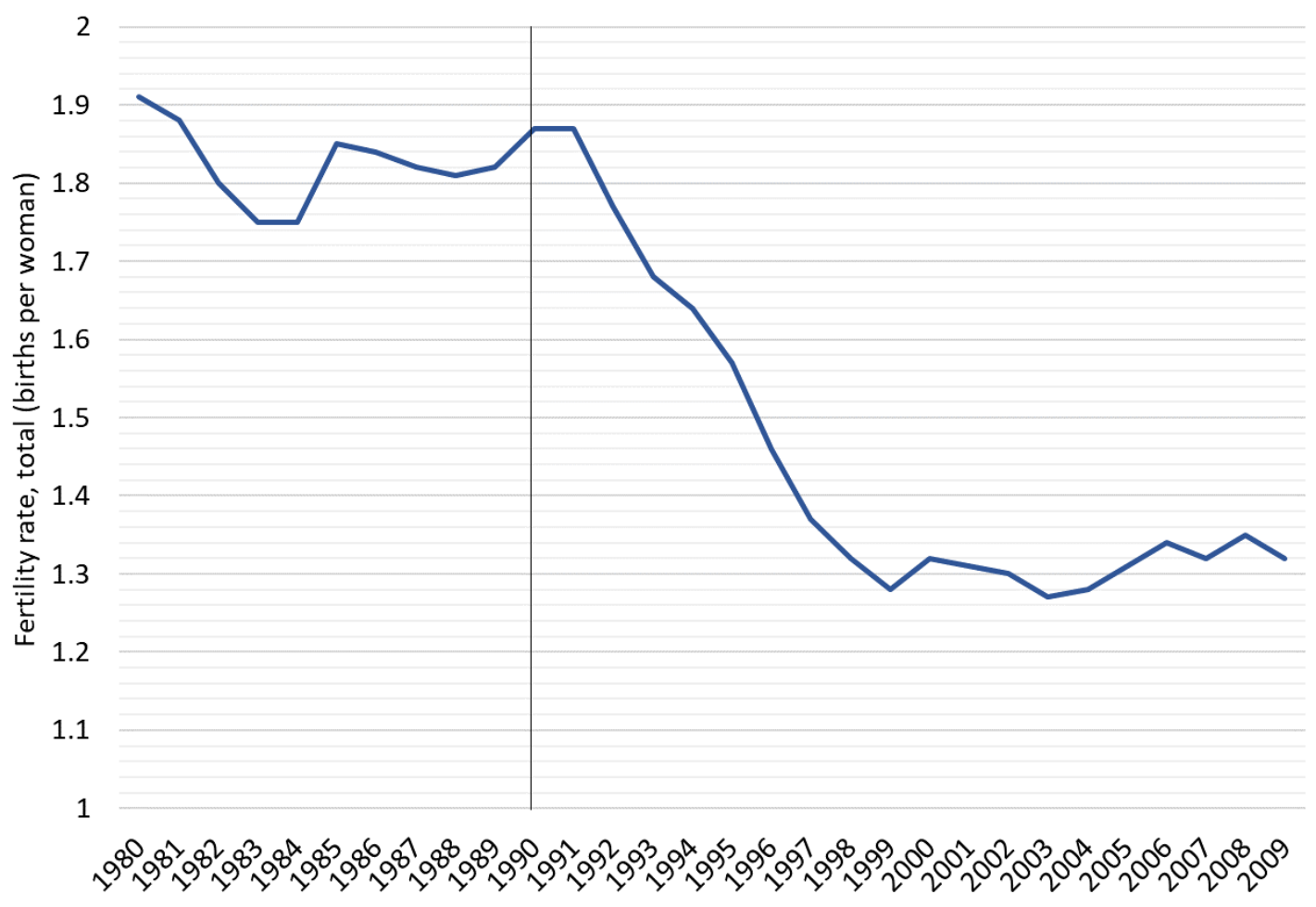

Source: (World Bank 2020) 
Figure 2. The privatization-fertility mechanism

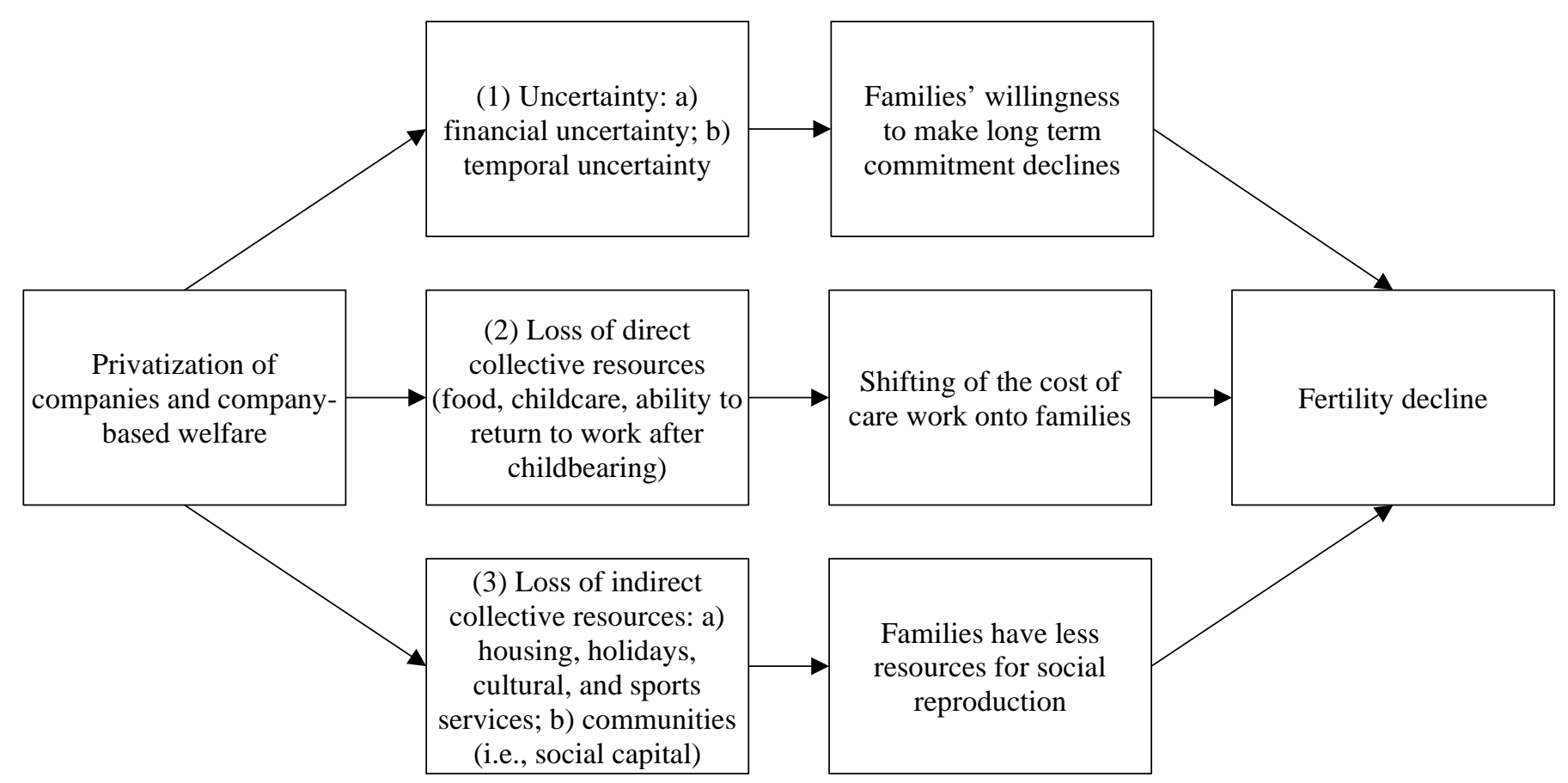


Figure 3. Privatization and fertility 1989-2006, annual town-level means

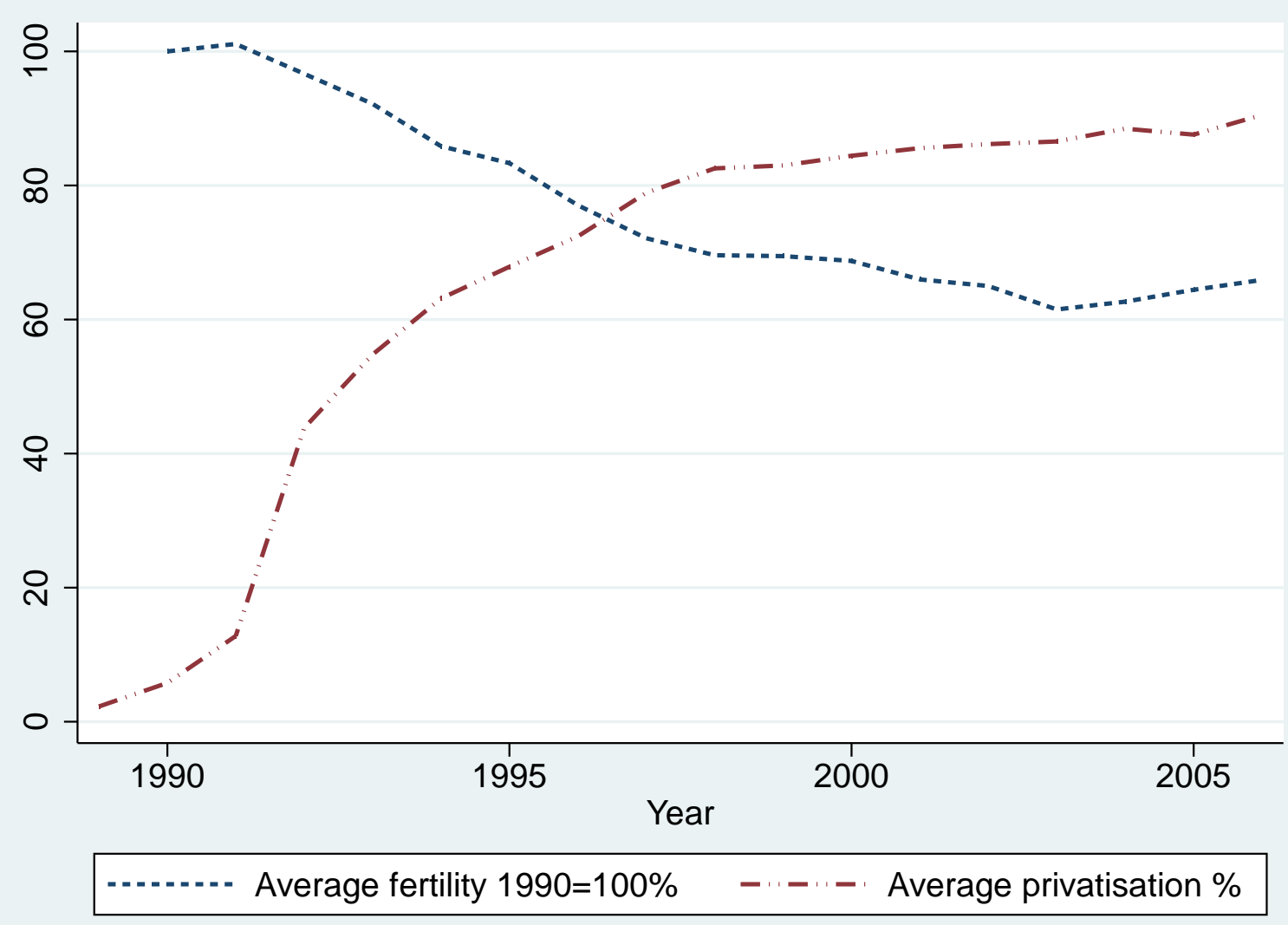


Figure 4. Privatization and fertility 1989-2012, annual country-level means

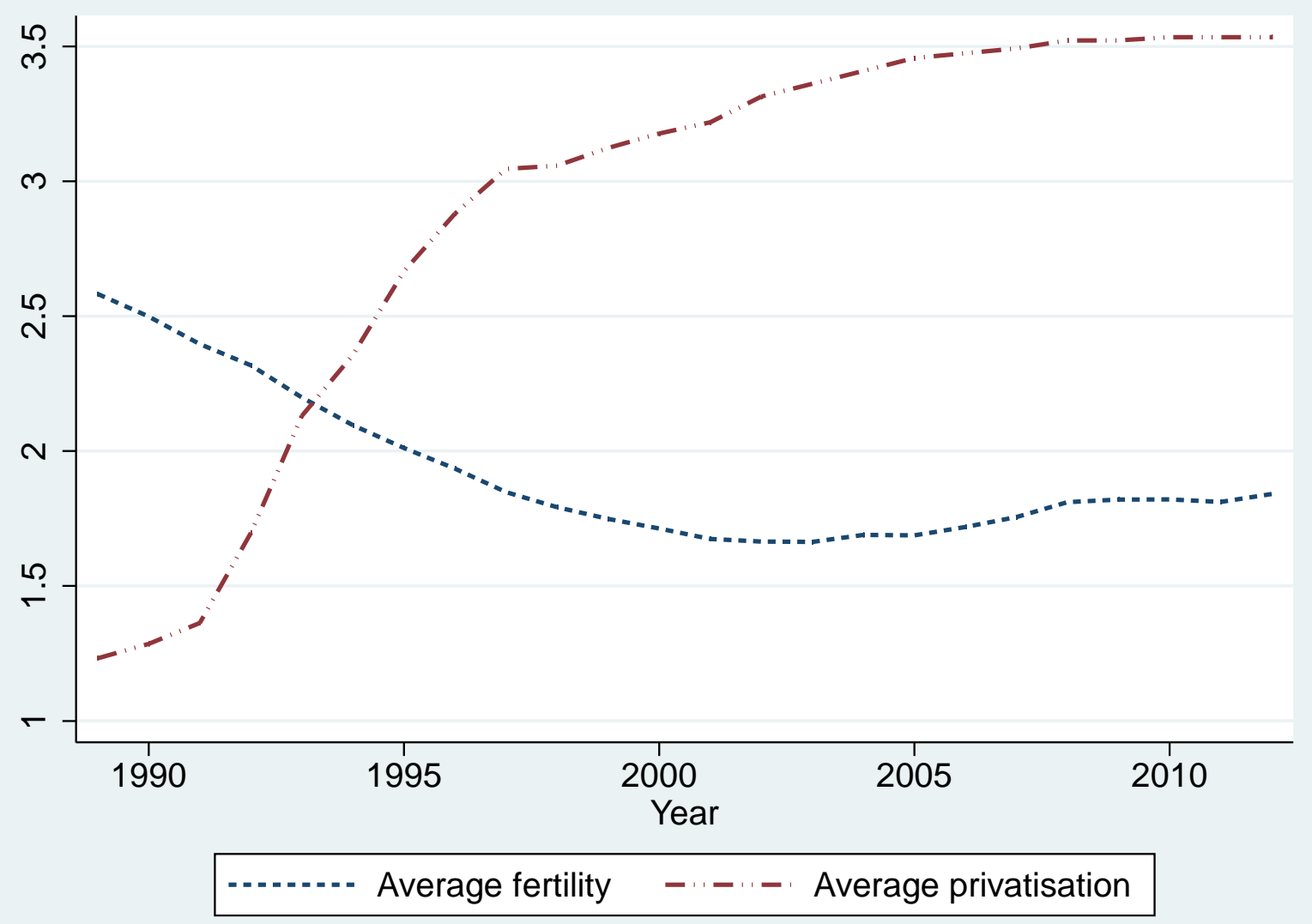


Figure 5. Privatization and fertility 1989-2012, country-level fixed effects models

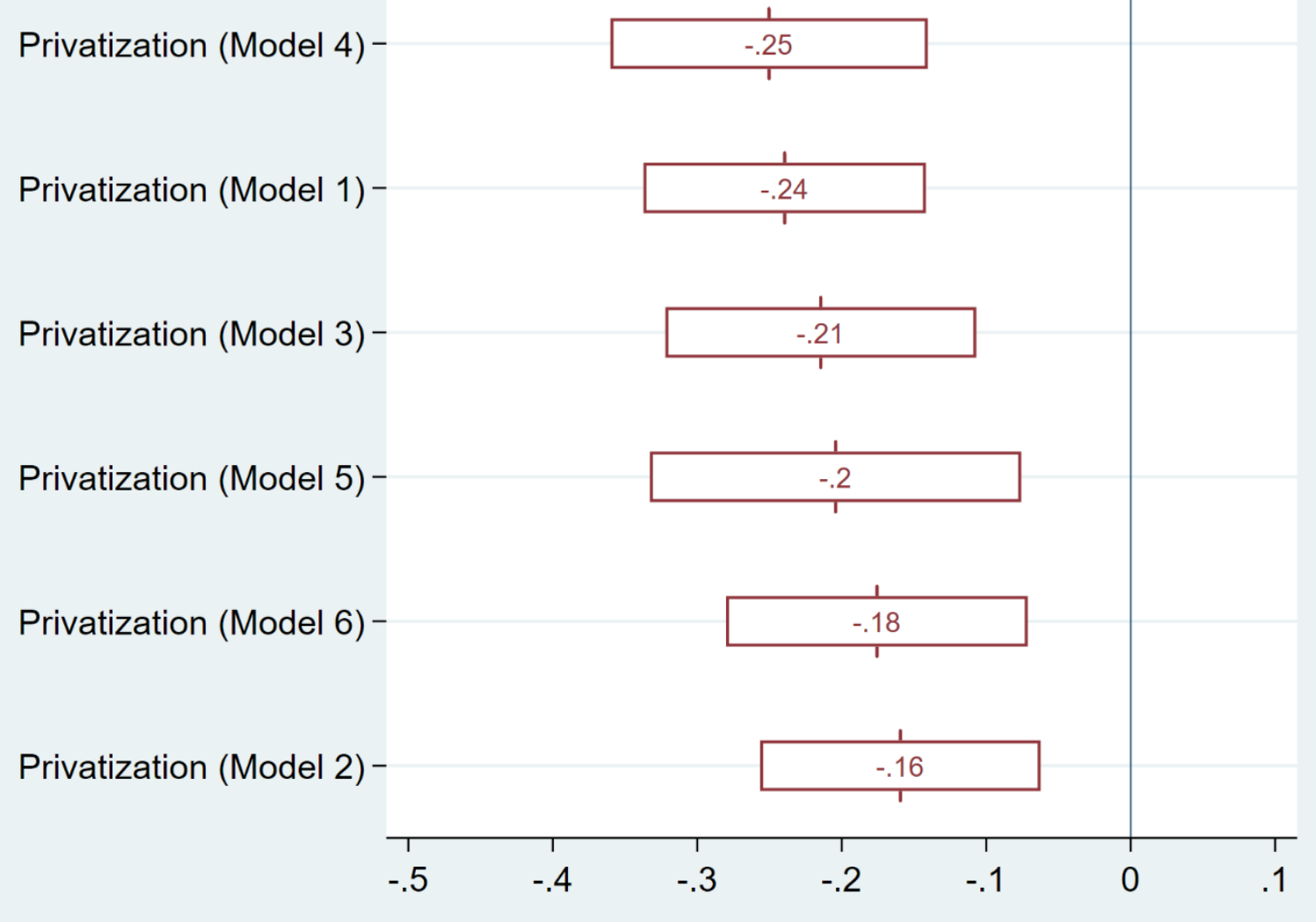

Note:

Dependent variable: total fertility rate. Privatization is lagged one year. Cluster-robust standard errors were used.

The following controls were used: Model 1) population, year; Model 2) population, year, unemployment, GDP per capita, government consumption, consumer price index; Model 3) population, year, urban population, employment in industry, employment in services; Model 4) population, year, infant mortality, homicides, net migration; Model 5) population, year, hospital beds, physicians; Model 6) female tertiary school enrolment, female labor force participation, female/male employment rate, female unemployment. 


\section{Appendix}

Table A1. Descriptive statistics of the town-level variables

\begin{tabular}{|c|c|c|c|c|c|c|c|}
\hline \multirow{4}{*}{ 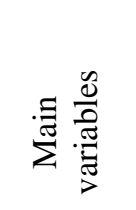 } & & Mean & Std. Dev. & Min & Max & $\mathrm{N}$ & Rho \\
\hline & Fertility & 1.51 & 0.39 & 0.73 & 3.23 & $N=884$ & 0.292 \\
\hline & Privatization \% (0-100) & 65.34 & 34.19 & 0 & 100 & $\mathrm{~N}=935$ & 0.112 \\
\hline & No of inhabitants & 25129.84 & 20570.33 & 0 & 85932 & $\mathrm{~N}=884$ & 0.995 \\
\hline \multirow{2}{*}{ 灾 } & Unemployment & 8.08 & 4.27 & 0 & 29.4 & $N=883$ & 0.605 \\
\hline & Income per capita (10,000 HUF) & 29.73 & 19.97 & 4.2 & 112.88 & $\mathrm{~N}=883$ & 0.059 \\
\hline \multirow{3}{*}{ 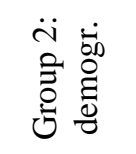 } & Infant mortality per 1000 inhabitant & 1.03 & 2.16 & 0 & 23.94 & $\mathrm{~N}=882$ & 0.062 \\
\hline & In-migration per 1000 inhabitant & 37.98 & 8.92 & 13.69 & 78.78 & $\mathrm{~N}=882$ & 0.577 \\
\hline & Out-migration per 1000 inhabitant & 40.75 & 8.76 & 18.2 & 71.86 & $\mathrm{~N}=882$ & 0.581 \\
\hline \multirow{3}{*}{ 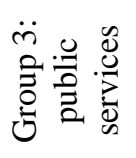 } & Kindergarten places per 1000 inhabitant & 3.21 & 2.34 & 0 & 11.85 & $\mathrm{~N}=874$ & 0.64 \\
\hline & No of hospital beds per 1000 inhabitant & 10.87 & 11.23 & 0 & 43.27 & $\mathrm{~N}=882$ & 0.97 \\
\hline & Primary school teachers per 1000 inhabitant & 9.29 & 1.47 & 5.42 & 17.72 & $\mathrm{~N}=830$ & 0.534 \\
\hline \multirow{3}{*}{ 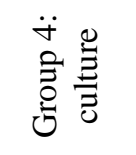 } & Calvinist population \% 2001 & 16.07 & 14.86 & 0.99 & 60.2 & $\mathrm{~N}=936$ & 1 \\
\hline & Catholic population \% 2001 & 49.9 & 22.24 & 3.64 & 89.31 & $\mathrm{~N}=936$ & 1 \\
\hline & Roma population \% 2001 & 2.35 & 3.2 & 0 & 15.24 & $\mathrm{~N}=936$ & 1 \\
\hline \multirow{3}{*}{ 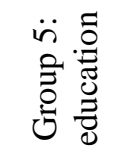 } & Population with max primary degree \% 2001 & 0.24 & 0.03 & 0.17 & 0.31 & $\mathrm{~N}=936$ & 1 \\
\hline & Population with max secondary degree \% 2001 & 0.08 & 0.02 & 0.03 & 0.13 & $\mathrm{~N}=936$ & 1 \\
\hline & Population with max tertiary degree \% 2001 & 0.08 & 0.03 & 0.02 & 0.16 & $\mathrm{~N}=936$ & 1 \\
\hline \multirow{3}{*}{ 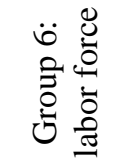 } & Male employment rate 2001 & 0.58 & 0.08 & 0.4 & 0.72 & $\mathrm{~N}=936$ & 1 \\
\hline & Female employment rate 2001 & 0.49 & 0.07 & 0.29 & 0.62 & $\mathrm{~N}=936$ & 1 \\
\hline & Female to male employment ratio 2001 & 0.87 & 0.07 & 0.71 & 1.05 & $\mathrm{~N}=936$ & 1 \\
\hline \multirow{5}{*}{ 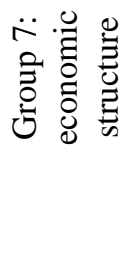 } & Employment: industry 2001 & 0.18 & 0.05 & 0.12 & 0.3 & $N=936$ & 1 \\
\hline & Employment: forestry \& agriculture 2001 & 0.01 & 0.01 & 0 & 0.04 & $\mathrm{~N}=936$ & 1 \\
\hline & Employment: commerce \& services 2001 & 0.08 & 0.02 & 0.05 & 0.14 & $\mathrm{~N}=936$ & 1 \\
\hline & Year & 1997.5 & 5.19 & 1989 & 2006 & $\mathrm{~N}=936$ & 0 \\
\hline & National real income growth \% & 101.06 & 3.73 & 94.6 & 106.5 & $\mathrm{~N}=832$ & 0 \\
\hline \multirow{6}{*}{ 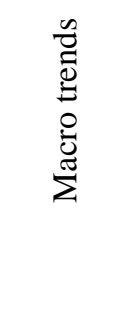 } & National unemployment rate \% & 7.78 & 2.46 & 1.7 & 12.1 & $\mathrm{~N}=884$ & 0 \\
\hline & National inflation rate \% & 115.72 & 9.4 & 103.6 & 135 & $N=936$ & 0 \\
\hline & School enrolment, tertiary, female \% & 38.52 & 21.59 & 14.96 & 80.64 & $\mathrm{~N}=884$ & 0 \\
\hline & Government consumption (GFCE) (\% of GDP) & 22.84 & 2.02 & 20.89 & 27.81 & $\mathrm{~N}=832$ & 0 \\
\hline & National female to male employment ratio \% & 75.89 & 5.47 & 69.87 & 88.12 & $\mathrm{~N}=936$ & 0 \\
\hline & National share of $1 \%$ in pre-tax income $\%$ & 8.03 & 1.58 & 3.5 & 10.06 & $\mathrm{~N}=832$ & 0 \\
\hline
\end{tabular}


Privatisation and fertility

Table A2. Descriptive statistics of the country-level variables

\begin{tabular}{|c|c|c|c|c|c|c|c|}
\hline & & Mean & Std. Dev. & Min & Max & $\mathrm{N}$ & Rho \\
\hline \multirow{4}{*}{ 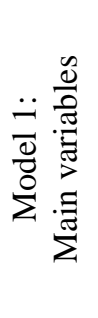 } & Fertility & 1.92 & 0.76 & 1.09 & 5.34 & 664 & 0.79 \\
\hline & Privatization & 2.89 & 1.01 & 1.00 & 4.17 & 672 & 0.27 \\
\hline & Population, total (million) & 14.16 & 27.75 & 0.60 & 148.69 & 671 & 0.99 \\
\hline & Year & 2000.50 & 6.93 & 1989.00 & 2012.00 & 672 & 0 \\
\hline \multirow{4}{*}{ 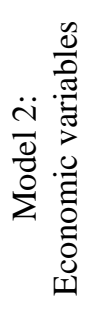 } & Unemployment, total (\%) & 12.03 & 7.41 & 0.60 & 37.25 & 616 & 0.79 \\
\hline & GDP per capita (2010 US\$, 1000\$) & 5.66 & 4.81 & 0.37 & 25.43 & 613 & 0.86 \\
\hline & Govt consumption exp (\% of GDP) & 17.49 & 4.77 & 5.86 & 43.25 & 588 & 0.54 \\
\hline & Consumer price index (2010=100\%) (/10) & 6.22 & 3.33 & 0.00 & 12.39 & 491 & 0.13 \\
\hline \multirow{3}{*}{ 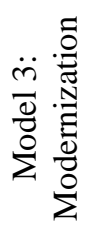 } & Urban population (\%) & 56.12 & 11.29 & 26.50 & 75.70 & 671 & 0.96 \\
\hline & Employment in industry (\% of total) & 26.01 & 8.53 & 8.22 & 45.99 & 616 & 0.93 \\
\hline & Employment in services (\% of total) & 47.51 & 10.41 & 22.80 & 76.80 & 616 & 0.82 \\
\hline \multirow{3}{*}{ 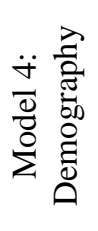 } & Mortality, infant (per 1,000) & 22.95 & 19.58 & 2.40 & 88.60 & 672 & 0.81 \\
\hline & Homicides (per 100,000) & 6.20 & 5.55 & 0.50 & 43.10 & 565 & 0.70 \\
\hline & Net migration $(100,000)$ & -0.48 & 4.85 & -14.39 & 24.90 & 140 & 0.82 \\
\hline \multirow{2}{*}{ 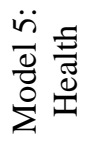 } & Hospital beds (per 1,000) & 7.42 & 2.72 & 2.50 & 14.08 & 613 & 0.58 \\
\hline & Physicians (per 1,000 people) & 2.84 & 0.84 & 0.65 & 7.09 & 600 & 0.69 \\
\hline \multirow{4}{*}{ 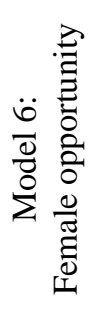 } & Tertiary school enrolment, female (\%) & 47.40 & 25.51 & 5.99 & 108.86 & 477 & 0.49 \\
\hline & Labor force participation, female (\%) & 49.65 & 7.39 & 29.10 & 65.66 & 644 & 0.90 \\
\hline & Female/male employment rate (\%) & 75.05 & 8.10 & 52.36 & 96.41 & 644 & 0.92 \\
\hline & Unemployment, female (\%) & 11.88 & 8.29 & 0.07 & 44.50 & 434 & 0.85 \\
\hline
\end{tabular}


Table A3. Privatization and fertility 1989-2006, town-level random-effects models

\begin{tabular}{|c|c|c|c|c|c|c|}
\hline & (1) & (2) & (3) & (4) & (5) & (6) \\
\hline & $\mathrm{b} / \mathrm{se}$ & $\mathrm{b} / \mathrm{se}$ & $\mathrm{b} / \mathrm{se}$ & $\mathrm{b} / \mathrm{se}$ & $\mathrm{b} / \mathrm{se}$ & $\mathrm{b} / \mathrm{se}$ \\
\hline Privatization \% (0-100) & $\begin{array}{l}-0.0048^{* * *} \\
(0.00)\end{array}$ & $\begin{array}{l}-0.0049 * * * \\
(0.00)\end{array}$ & $\begin{array}{l}-0.0049 * * * \\
(0.00)\end{array}$ & $\begin{array}{l}-0.0049 * * * \\
(0.00)\end{array}$ & $\begin{array}{l}-0.0049 * * * \\
(0.00)\end{array}$ & $\begin{array}{l}-0.0049 * * * \\
(0.00)\end{array}$ \\
\hline Income per capita (10000 HUF) & $\begin{array}{l}-0.0052 * * * \\
(0.00)\end{array}$ & $\begin{array}{l}-0.0051^{* * *} \\
(0.00)\end{array}$ & $\begin{array}{l}-0.0051^{* * *} \\
(0.00)\end{array}$ & $\begin{array}{l}-0.0051^{* * *} \\
(0.00)\end{array}$ & $\begin{array}{l}-0.0051^{* * *} \\
(0.00)\end{array}$ & $\begin{array}{l}-0.0052^{* * *} \\
(0.00)\end{array}$ \\
\hline Unemployment & $\begin{array}{l}0.0061 \\
(0.00)\end{array}$ & $\begin{array}{l}0.0100^{* *} \\
(0.00)\end{array}$ & $\begin{array}{l}0.0088^{*} \\
(0.00)\end{array}$ & $\begin{array}{l}0.0083^{*} \\
(0.00)\end{array}$ & $\begin{array}{l}0.0083^{*} \\
(0.00)\end{array}$ & $\begin{array}{l}0.0073^{*} \\
(0.00)\end{array}$ \\
\hline Calvinist population \% 2001 & $\begin{array}{l}0.0047 \\
(0.00)\end{array}$ & & & & & $\begin{array}{l}0.0063^{* *} \\
(0.00)\end{array}$ \\
\hline Catholic population \% 2001 & $\begin{array}{l}-0.0002 \\
(0.00)\end{array}$ & & & & & $\begin{array}{l}0.0001 \\
(0.00)\end{array}$ \\
\hline Roma population \% 2001 & $\begin{array}{l}0.0334^{* * *} \\
(0.01)\end{array}$ & & & & & $\begin{array}{l}0.0462^{* * *} \\
(0.01)\end{array}$ \\
\hline Population with primary degree \% 2001 & & $\begin{array}{l}-1.4436 \\
(1.39)\end{array}$ & & & & $\begin{array}{l}0.3135 \\
(1.19)\end{array}$ \\
\hline Population with secondary degree \% 2001 & & $\begin{array}{l}-2.9135 \\
(2.05)\end{array}$ & & & & $\begin{array}{l}-0.6325 \\
(1.28)\end{array}$ \\
\hline Population with tertiary degree $\% 2001$ & & $\begin{array}{l}-1.3392 \\
(1.88)\end{array}$ & & & & $\begin{array}{l}3.1663 \\
(1.96)\end{array}$ \\
\hline Male employment rate 2001 & & & $\begin{array}{l}-0.8617 \\
(0.45)\end{array}$ & & & \\
\hline Female employment rate 2001 & & & & $\begin{array}{l}-1.1587^{*} \\
(0.49)\end{array}$ & & $\begin{array}{l}0.2245 \\
(1.00)\end{array}$ \\
\hline Female/male employment ratio 2001 & & & & $\begin{array}{l}-0.3560 \\
(0.48)\end{array}$ & & $\begin{array}{l}-0.5297 \\
(0.38)\end{array}$ \\
\hline Employment share: industry 2001 & & & & & $\begin{array}{l}-0.9689 \\
(0.57)\end{array}$ & $\begin{array}{l}1.5221 \\
(1.17)\end{array}$ \\
\hline Employment share: forestry \& agricult. 2001 & & & & & $\begin{array}{l}0.8915 \\
(3.27)\end{array}$ & $\begin{array}{l}2.6814 \\
(2.28)\end{array}$ \\
\hline Employment share: commerce \& services 2001 & & & & & $\begin{array}{l}-4.8160 * * * \\
(1.35)\end{array}$ & $\begin{array}{l}-2.1795 \\
(1.57)\end{array}$ \\
\hline Constant & $\begin{array}{l}1.8019 * * * \\
(0.12)\end{array}$ & $\begin{array}{l}2.6451^{* * *} \\
(0.46)\end{array}$ & $\begin{array}{l}2.4666^{* * *} \\
(0.28)\end{array}$ & $\begin{array}{l}2.8214 * * * \\
(0.42)\end{array}$ & $\begin{array}{l}2.5077^{* * *} \\
(0.21)\end{array}$ & $\begin{array}{l}1.6623 * * \\
(0.51)\end{array}$ \\
\hline No. of observations[town-years] & 934 & 934 & 934 & 934 & 934 & 934 \\
\hline No. of groups[towns] & 52 & 52 & 52 & 52 & 52 & 52 \\
\hline
\end{tabular}

$* \mathrm{p}<0.05, * * \mathrm{p}<0.01, * * * \mathrm{p}<0.001$

Note:

Dependent variable: total fertility rate. Privatization is lagged one year.

All models are adjusted for annual population size. Cluster-robust standard errors are in parentheses. 
Table A4. Privatization and fertility 1989-2006, town-level fixed effects models plus years

\begin{tabular}{|c|c|c|c|c|c|}
\hline & (1) & (2) & (3) & (4) & (5) \\
\hline & $\mathrm{b} / \mathrm{se}$ & $\mathrm{b} / \mathrm{se}$ & $\mathrm{b} / \mathrm{se}$ & $\mathrm{b} / \mathrm{se}$ & $\mathrm{b} / \mathrm{se}$ \\
\hline L.Privatization \% (0-100) & $\begin{array}{l}-0.0032 * * * \\
(0.00)\end{array}$ & $\begin{array}{l}-0.0023^{* * *} \\
(0.00)\end{array}$ & $\begin{array}{l}-0.0022 * * * \\
(0.00)\end{array}$ & $\begin{array}{l}-0.0020^{* *} \\
(0.00)\end{array}$ & $\begin{array}{l}-0.0018^{* *} \\
(0.00)\end{array}$ \\
\hline Year & $\begin{array}{l}-0.0301^{* * *} \\
(0.00)\end{array}$ & $\begin{array}{l}-0.0654^{* * *} \\
(0.01)\end{array}$ & $\begin{array}{l}-0.0649 * * * \\
(0.01)\end{array}$ & $\begin{array}{l}-0.0633^{* * *} \\
(0.01)\end{array}$ & $\begin{array}{l}-0.0647^{* * *} \\
(0.01)\end{array}$ \\
\hline Unemployment & & $\begin{array}{l}0.0110^{* *} \\
(0.00)\end{array}$ & $\begin{array}{l}0.0115^{* *} \\
(0.00)\end{array}$ & $\begin{array}{l}0.0085^{*} \\
(0.00)\end{array}$ & $\begin{array}{l}0.0110^{* *} \\
(0.00)\end{array}$ \\
\hline Income per capita (10000 HUF) & & $\begin{array}{l}0.0082 * * * \\
(0.00)\end{array}$ & $\begin{array}{l}0.0070^{* * *} \\
(0.00)\end{array}$ & $\begin{array}{l}0.0068^{* *} \\
(0.00)\end{array}$ & $\begin{array}{l}0.0067 * * * \\
(0.00)\end{array}$ \\
\hline Infant mortality per 1000 inhabitant & & & $\begin{array}{l}-0.0001 \\
(0.00)\end{array}$ & & $\begin{array}{l}-0.0011 \\
(0.00)\end{array}$ \\
\hline In-migration per 1000 inhabitant & & & $\begin{array}{l}0.0037^{*} \\
(0.00)\end{array}$ & & $\begin{array}{l}0.0032 \\
(0.00)\end{array}$ \\
\hline Out-migration per 1000 inhabitant & & & $\begin{array}{l}0.0043 \\
(0.00)\end{array}$ & & $\begin{array}{l}0.0038 \\
(0.00)\end{array}$ \\
\hline Kindergarten places per 1000 inhabitant & & & & $\begin{array}{l}-0.0006 \\
(0.01)\end{array}$ & $\begin{array}{l}-0.0030 \\
(0.01)\end{array}$ \\
\hline No of hospital beds per 1000 inhabitant & & & & $\begin{array}{l}0.0134 \\
(0.01)\end{array}$ & $\begin{array}{l}0.0120 \\
(0.01)\end{array}$ \\
\hline Primary school teachers per 1000 inhabitant & & & & $\begin{array}{l}0.0208^{*} \\
(0.01)\end{array}$ & $\begin{array}{l}0.0215^{*} \\
(0.01)\end{array}$ \\
\hline Constant & $\begin{array}{l}61.5343^{* * *} \\
(7.06)\end{array}$ & $\begin{array}{l}131.5502^{* * *} \\
(18.73)\end{array}$ & $\begin{array}{l}130.5536^{* * *} \\
(15.38)\end{array}$ & $\begin{array}{l}127.5899 * * * \\
(18.25)\end{array}$ & $\begin{array}{l}129.9481^{* * *} \\
(16.67)\end{array}$ \\
\hline No. of observations[town-years] & 935 & 934 & 933 & 822 & 822 \\
\hline No. of groups[towns] & 52 & 52 & 52 & 52 & 52 \\
\hline
\end{tabular}

${ }^{*} \mathrm{p}<0.05,{ }^{* *} \mathrm{p}<0.01, * * * \mathrm{p}<0.001$

Note:

Dependent variable: total fertility rate. Privatization is lagged one year.

All models are adjusted for annual population size. Cluster-robust standard errors are in parentheses. 
Table A5. Privatization and fertility 1989-2012, country-level fixed effects models

\begin{tabular}{|c|c|c|c|c|c|c|}
\hline & (1) & (2) & (3) & (4) & (5) & (6) \\
\hline & $\mathrm{b} / \mathrm{se}$ & $\mathrm{b} / \mathrm{se}$ & $\mathrm{b} / \mathrm{se}$ & $\mathrm{b} / \mathrm{se}$ & $\mathrm{b} / \mathrm{se}$ & $\mathrm{b} / \mathrm{se}$ \\
\hline Privatization & $\begin{array}{l}-0.2395 * * * \\
(0.04)\end{array}$ & $\begin{array}{l}-0.1594^{* * *} \\
(0.03)\end{array}$ & $\begin{array}{l}-0.2145^{* * *} \\
(0.04)\end{array}$ & $\begin{array}{l}-0.2503^{* * *} \\
(0.04)\end{array}$ & $\begin{array}{l}-0.2042^{* * * *} \\
(0.05)\end{array}$ & $\begin{array}{l}-0.1756^{* * *} \\
(0.04)\end{array}$ \\
\hline Unemployment, total (\%) & & $\begin{array}{l}-0.0036 \\
(0.01)\end{array}$ & & & & \\
\hline GDP per capita (2010 US\$, 1000\$) & & $\begin{array}{l}0.0599 * * \\
(0.02)\end{array}$ & & & & \\
\hline Government consumption (\% of GDP) & & $\begin{array}{l}0.0249 * * * \\
(0.00)\end{array}$ & & & & \\
\hline Consumer price index (10\%) & & $\begin{array}{l}0.0431^{*} \\
(0.02)\end{array}$ & & & & \\
\hline Urban population (\%) & & & $\begin{array}{l}0.0006 \\
(0.02)\end{array}$ & & & \\
\hline Employment in industry (\% of total) & & & $\begin{array}{l}0.0171 \\
(0.01)\end{array}$ & & & \\
\hline Employment in services (\% of total) & & & $\begin{array}{l}0.0214^{\circ} \\
(0.01)\end{array}$ & & & \\
\hline Infant mortality rate (per 1,000 ) & & & & $\begin{array}{l}0.0071 \\
(0.01)\end{array}$ & & \\
\hline Homicides (per 100,000 people) & & & & $\begin{array}{l}0.0027 \\
(0.01)\end{array}$ & & \\
\hline Net migration $(100,000)$ & & & & $\begin{array}{l}0.0170 \\
(0.01)\end{array}$ & & \\
\hline Hospital beds (per 1,000 people) & & & & & $\begin{array}{l}0.0180 \\
(0.03)\end{array}$ & \\
\hline Physicians (per 1,000 people) & & & & & $\begin{array}{l}0.0929 * \\
(0.04)\end{array}$ & \\
\hline Tertiary school enrollment, female (\%) & & & & & & $\begin{array}{l}0.0036 \\
(0.00)\end{array}$ \\
\hline Labor force participation, female (\%) & & & & & & $\begin{array}{l}0.0375^{\circ} \\
(0.02)\end{array}$ \\
\hline Female/male employment rate (\%) & & & & & & $\begin{array}{l}-0.0268 * \\
(0.01)\end{array}$ \\
\hline Unemployment, female (\%) & & & & & & $\begin{array}{l}-0.0011 \\
(0.01)\end{array}$ \\
\hline Constant & $\begin{array}{l}9.0146 \\
(12.54)\end{array}$ & $\begin{array}{l}63.8958 * * \\
(22.80)\end{array}$ & $\begin{array}{l}29.2174 \\
(17.38)\end{array}$ & $\begin{array}{l}-19.5853 \\
(16.25)\end{array}$ & $\begin{array}{l}6.9020 \\
(13.99)\end{array}$ & $\begin{array}{l}11.4553 \\
(17.39)\end{array}$ \\
\hline No. of observations[Country-years] & 637 & 454 & 610 & 122 & 577 & 362 \\
\hline No. of groups[Countries] & 28 & 25 & 28 & 28 & 28 & 26 \\
\hline
\end{tabular}

${ }^{\circ} \mathrm{p}<0.10,{ }^{*} \mathrm{p}<0.05,{ }^{* *} \mathrm{p}<0.01,{ }^{* * *} \mathrm{p}<0.001$

Note: Dependent variable: total fertility rate. Privatization is lagged one year.

All models are adjusted for countries' population size and time trend.

Cluster-robust standard errors are in parentheses 
Table A6. Privatization and fertility 1989-2012 (Excluding members of the Soviet Union)

\begin{tabular}{|c|c|c|c|c|c|c|}
\hline & (1) & (2) & (3) & (4) & (5) & (6) \\
\hline & $\mathrm{b} / \mathrm{se}$ & $\mathrm{b} / \mathrm{se}$ & $\mathrm{b} / \mathrm{se}$ & $\mathrm{b} / \mathrm{se}$ & $\mathrm{b} / \mathrm{se}$ & $\mathrm{b} / \mathrm{se}$ \\
\hline Privatization & $\begin{array}{l}-0.1982 * * * \\
(0.05)\end{array}$ & $\begin{array}{l}-0.1934 * * \\
(0.06)\end{array}$ & $\begin{array}{l}-0.2184 * * * \\
(0.05)\end{array}$ & $\begin{array}{l}-0.1138 * \\
(0.05)\end{array}$ & $\begin{array}{l}-0.2369 * * * \\
(0.05)\end{array}$ & $\begin{array}{l}-0.1230 * * \\
(0.03)\end{array}$ \\
\hline Unemployment, total (\%) & & $\begin{array}{l}-0.0133^{\circ} \\
(0.01)\end{array}$ & & & & \\
\hline GDP per capita (2010 US\$, 1000\$) & & $\begin{array}{l}0.0500 * \\
(0.02)\end{array}$ & & & & \\
\hline Government consumption (\% of GDP) & & $\begin{array}{l}0.0232 * * \\
(0.01)\end{array}$ & & & & \\
\hline Consumer price index (10\%) & & $\begin{array}{l}0.0744^{\circ} \\
(0.04)\end{array}$ & & & & \\
\hline Urban population (\%) & & & $\begin{array}{l}0.0110 \\
(0.02)\end{array}$ & & & \\
\hline Employment in industry (\% of total) & & & $\begin{array}{l}-0.0189 \\
(0.02)\end{array}$ & & & \\
\hline Employment in services (\% of total) & & & $\begin{array}{l}0.0256 \\
(0.02)\end{array}$ & & & \\
\hline Infant mortality rate (per 1,000 ) & & & & $\begin{array}{l}0.0412 \\
(0.03)\end{array}$ & & \\
\hline Homicides (per 100,000 people) & & & & $\begin{array}{l}0.0023 \\
(0.00)\end{array}$ & & \\
\hline Net migration $(100,000)$ & & & & $\begin{array}{l}-0.0124 \\
(0.02)\end{array}$ & & \\
\hline Hospital beds (per 1,000 people) & & & & & $\begin{array}{l}-0.0731 \\
(0.04)\end{array}$ & \\
\hline Physicians (per 1,000 people) & & & & & $\begin{array}{l}0.3097 \\
(0.19)\end{array}$ & \\
\hline Tertiary school enrollment, female (\%) & & & & & & $\begin{array}{l}0.0056^{\circ} \\
(0.00)\end{array}$ \\
\hline Labor force participation, female (\%) & & & & & & $\begin{array}{l}0.0569 * \\
(0.02)\end{array}$ \\
\hline Female/male employment rate (\%) & & & & & & $\begin{array}{l}-0.0256 \\
(0.02)\end{array}$ \\
\hline Unemployment, female (\%) & & & & & & $\begin{array}{l}-0.0056 \\
(0.00)\end{array}$ \\
\hline Constant & $\begin{array}{l}19.0439 \\
(14.59)\end{array}$ & $\begin{array}{l}94.1413 * * \\
(27.95)\end{array}$ & $\begin{array}{l}55.3822 * \\
(23.50)\end{array}$ & $\begin{array}{l}-23.6069 \\
(21.17)\end{array}$ & $\begin{array}{l}23.2609 \\
(15.68)\end{array}$ & $\begin{array}{l}55.0921 * \\
(23.79)\end{array}$ \\
\hline No. of observations[Country-years] & 292 & 239 & 280 & 53 & 234 & 206 \\
\hline No. of groups[Countries] & 13 & 13 & 13 & 13 & 13 & 12 \\
\hline
\end{tabular}

${ }^{\circ} \mathrm{p}<0.10,{ }^{*} \mathrm{p}<0.05,{ }^{* *} \mathrm{p}<0.01, * * * \mathrm{p}<0.001$

Note: Dependent variable: total fertility rate. Privatization is lagged one year.

All models are adjusted for countries' population size and time trend.

Cluster-robust standard errors are in parentheses 
Table A7. Privatization and fertility 1989-2012 (Members of the Soviet Union)

\begin{tabular}{|c|c|c|c|c|c|c|}
\hline & (1) & (2) & (3) & (4) & (5) & (6) \\
\hline & $\mathrm{b} / \mathrm{se}$ & $\mathrm{b} / \mathrm{se}$ & $\mathrm{b} / \mathrm{se}$ & $\mathrm{b} / \mathrm{se}$ & $\mathrm{b} / \mathrm{se}$ & $\mathrm{b} / \mathrm{se}$ \\
\hline Privatization & $\begin{array}{l}-0.2620 * * * \\
(0.05)\end{array}$ & $\begin{array}{l}-0.1844 * * * \\
(0.03)\end{array}$ & $\begin{array}{l}-0.1794 * * \\
(0.05)\end{array}$ & $\begin{array}{l}-0.2906 * * * \\
(0.06)\end{array}$ & $\begin{array}{l}-0.1791^{* *} \\
(0.06)\end{array}$ & $\begin{array}{l}-0.1266 * * * \\
(0.03)\end{array}$ \\
\hline Unemployment, total (\%) & & $\begin{array}{l}0.0009 \\
(0.01)\end{array}$ & & & & \\
\hline GDP per capita (2010 US\$, 1000\$) & & $\begin{array}{l}0.0607 * \\
(0.02)\end{array}$ & & & & \\
\hline Government consumption (\% of GDP) & & $\begin{array}{l}0.0243^{* * *} \\
(0.01)\end{array}$ & & & & \\
\hline Consumer price index (10\%) & & $\begin{array}{l}0.0033 \\
(0.02)\end{array}$ & & & & \\
\hline Urban population (\%) & & & $\begin{array}{l}-0.0018 \\
(0.03)\end{array}$ & & & \\
\hline Employment in industry (\% of total) & & & $\begin{array}{l}0.0507 * * \\
(0.01)\end{array}$ & & & \\
\hline Employment in services (\% of total) & & & $\begin{array}{l}0.0140 \\
(0.01)\end{array}$ & & & \\
\hline Infant mortality rate (per 1,000 ) & & & & $\begin{array}{l}0.0052 \\
(0.01)\end{array}$ & & \\
\hline Homicides (per 100,000 people) & & & & $\begin{array}{l}-0.0100 \\
(0.02)\end{array}$ & & \\
\hline Net migration $(100,000)$ & & & & $\begin{array}{l}0.0174 \\
(0.01)\end{array}$ & & \\
\hline Hospital beds (per 1,000 people) & & & & & $\begin{array}{l}0.0598^{*} \\
(0.02)\end{array}$ & \\
\hline Physicians (per 1,000 people) & & & & & $\begin{array}{l}0.0597^{\circ} \\
(0.03)\end{array}$ & \\
\hline Tertiary school enrollment, female (\%) & & & & & & $\begin{array}{l}0.0061^{* *} \\
(0.00)\end{array}$ \\
\hline Labor force participation, female (\%) & & & & & & $\begin{array}{l}0.0394^{* *} \\
(0.01)\end{array}$ \\
\hline Female/male employment rate (\%) & & & & & & $\begin{array}{l}-0.0454^{* * * *} \\
(0.01)\end{array}$ \\
\hline Unemployment, female (\%) & & & & & & $\begin{array}{l}0.0033 \\
(0.01)\end{array}$ \\
\hline Constant & $\begin{array}{l}7.5759 \\
(20.09)\end{array}$ & $\begin{array}{l}10.3010 \\
(22.80)\end{array}$ & $\begin{array}{l}26.9449 \\
(22.75)\end{array}$ & $\begin{array}{l}-16.2693 \\
(33.09)\end{array}$ & $\begin{array}{l}-10.1064 \\
(21.49)\end{array}$ & $\begin{array}{l}-9.5290 \\
(16.34)\end{array}$ \\
\hline No. of observations[Country-years] & 345 & 215 & 330 & 69 & 343 & 156 \\
\hline No. of groups[Countries] & 15 & 12 & 15 & 15 & 15 & 14 \\
\hline
\end{tabular}

${ }^{\circ} \mathrm{p}<0.10,{ }^{*} \mathrm{p}<0.05,{ }^{* *} \mathrm{p}<0.01, * * * \mathrm{p}<0.001$

Note: Dependent variable: total fertility rate. Privatization is lagged one year.

All models are adjusted for countries' population size and time trend.

Cluster-robust standard errors are in parentheses 
Table A8. Privatization and fertility 1989-2012 (Post-Socialist Europe)

\begin{tabular}{|c|c|c|c|c|c|c|}
\hline & $(1)$ & $(2)$ & (3) & $(4)$ & $(5)$ & $(6)$ \\
\hline & $\mathrm{b} / \mathrm{se}$ & $\mathrm{b} / \mathrm{se}$ & $\mathrm{b} / \mathrm{se}$ & $\mathrm{b} / \mathrm{se}$ & $\mathrm{b} / \mathrm{se}$ & $\mathrm{b} / \mathrm{se}$ \\
\hline Privatization & $\begin{array}{l}-0.2060^{* * *} \\
(0.02)\end{array}$ & $\begin{array}{l}-0.1220^{* * *} \\
(0.03)\end{array}$ & $\begin{array}{l}-0.2081^{* * *} \\
(0.03)\end{array}$ & $\begin{array}{l}-0.1925^{* * *} \\
(0.03)\end{array}$ & $\begin{array}{l}-0.2085^{* * *} \\
(0.04)\end{array}$ & $\begin{array}{l}-0.1737^{* * *} \\
(0.04)\end{array}$ \\
\hline Unemployment, total (\%) & & $\begin{array}{l}-0.0011 \\
(0.01)\end{array}$ & & & & \\
\hline GDP per capita (2010 US\$, 1000\$) & & $\begin{array}{l}0.0718^{* * *} \\
(0.02)\end{array}$ & & & & \\
\hline Government consumption (\% of GDP) & & $\begin{array}{l}0.0257^{* * *} \\
(0.00)\end{array}$ & & & & \\
\hline Consumer price index (10\%) & & $\begin{array}{l}0.0222 \\
(0.01)\end{array}$ & & & & \\
\hline Urban population (\%) & & & $\begin{array}{l}-0.0053 \\
(0.02)\end{array}$ & & & \\
\hline Employment in industry (\% of total) & & & $\begin{array}{l}-0.0089 \\
(0.01)\end{array}$ & & & \\
\hline Employment in services (\% of total) & & & $\begin{array}{l}0.0028 \\
(0.01)\end{array}$ & & & \\
\hline Infant mortality rate (per 1,000 ) & & & & $\begin{array}{l}0.0103 \\
(0.01)\end{array}$ & & \\
\hline Homicides (per 100,000 people) & & & & $\begin{array}{l}0.0020 \\
(0.01)\end{array}$ & & \\
\hline Net migration $(100,000)$ & & & & $\begin{array}{l}-0.0058 \\
(0.01)\end{array}$ & & \\
\hline Hospital beds (per 1,000 people) & & & & & $\begin{array}{l}-0.0174 \\
(0.03)\end{array}$ & \\
\hline Physicians (per 1,000 people) & & & & & $\begin{array}{l}0.0932 \\
(0.06)\end{array}$ & \\
\hline Tertiary school enrollment, female (\%) & & & & & & $\begin{array}{l}0.0042^{\circ} \\
(0.00)\end{array}$ \\
\hline Labor force participation, female (\%) & & & & & & $\begin{array}{l}0.0344^{\circ} \\
(0.02)\end{array}$ \\
\hline Female/male employment rate (\%) & & & & & & $\begin{array}{l}-0.0195 \\
(0.01)\end{array}$ \\
\hline Unemployment, female (\%) & & & & & & $\begin{array}{l}-0.0004 \\
(0.01)\end{array}$ \\
\hline Constant & $\begin{array}{l}5.4474 \\
(9.79)\end{array}$ & $\begin{array}{l}\text { 63.8998* } \\
(22.64)\end{array}$ & $\begin{array}{l}6.0200 \\
(10.73)\end{array}$ & $\begin{array}{l}-20.3651 \\
(12.57)\end{array}$ & $\begin{array}{l}10.3368 \\
(13.82)\end{array}$ & $\begin{array}{l}20.7292 \\
(16.81)\end{array}$ \\
\hline No. of observations[Country-years] & 499 & 395 & 478 & 100 & 458 & 337 \\
\hline No. of groups[Countries] & 22 & 21 & 22 & 22 & 22 & 21 \\
\hline
\end{tabular}

${ }^{\circ} \mathrm{p}<0.10,{ }^{*} \mathrm{p}<0.05,{ }^{* *} \mathrm{p}<0.01,{ }^{* * *} \mathrm{p}<0.001$

Note: Dependent variable: total fertility rate. Privatization is lagged one year.

All models are adjusted for countries' population size and time trend.

Cluster-robust standard errors are in parentheses 
Table A9. Privatization and fertility 1989-2012 (Post-Socialist Asia)

\begin{tabular}{|c|c|c|c|c|c|c|}
\hline & (1) & (2) & (3) & (4) & (5) & (6) \\
\hline & $\mathrm{b} / \mathrm{se}$ & $\mathrm{b} / \mathrm{se}$ & $\mathrm{b} / \mathrm{se}$ & $\mathrm{b} / \mathrm{se}$ & $\mathrm{b} / \mathrm{se}$ & $\mathrm{b} / \mathrm{se}$ \\
\hline Privatization & $\begin{array}{l}-0.4123^{\circ} \\
(0.16)\end{array}$ & $\begin{array}{l}-0.9060^{* * * *} \\
(0.06)\end{array}$ & $\begin{array}{l}-0.1931 \\
(0.15)\end{array}$ & $\begin{array}{l}-0.5543^{* *} \\
(0.11)\end{array}$ & $\begin{array}{l}-0.1646 \\
(0.21)\end{array}$ & $\begin{array}{l}-0.2965^{* *} \\
(0.05)\end{array}$ \\
\hline Unemployment, total (\%) & & $\begin{array}{l}-0.0590 \\
(0.05)\end{array}$ & & & & \\
\hline GDP per capita (2010 US\$, 1000\$) & & $\begin{array}{l}0.4167 * \\
(0.11)\end{array}$ & & & & \\
\hline Government consumption (\% of GDP) & & $\begin{array}{l}0.0177 \\
(0.01)\end{array}$ & & & & \\
\hline Consumer price index (10\%) & & $\begin{array}{l}0.0424 \\
(0.03)\end{array}$ & & & & \\
\hline Urban population (\%) & & & $\begin{array}{l}0.0065 \\
(0.02)\end{array}$ & & & \\
\hline Employment in industry (\% of total) & & & $\begin{array}{l}0.0626 \\
(0.03)\end{array}$ & & & \\
\hline Employment in services (\% of total) & & & $\begin{array}{l}0.0629 * \\
(0.02)\end{array}$ & & & \\
\hline Infant mortality rate (per 1,000 ) & & & & $\begin{array}{l}-0.0156 \\
(0.04)\end{array}$ & & \\
\hline Homicides (per 100,000 people) & & & & $\begin{array}{l}0.0472 \\
(0.07)\end{array}$ & & \\
\hline Net migration $(100,000)$ & & & & $\begin{array}{l}0.0397 \\
(0.04)\end{array}$ & & \\
\hline Hospital beds (per 1,000 people) & & & & & $\begin{array}{l}0.1235^{\circ} \\
(0.05)\end{array}$ & \\
\hline Physicians (per 1,000 people) & & & & & $\begin{array}{l}0.0882 \\
(0.09)\end{array}$ & \\
\hline Tertiary school enrollment, female (\%) & & & & & & $\begin{array}{l}-0.0031 \\
(0.00)\end{array}$ \\
\hline Labor force participation, female (\%) & & & & & & $\begin{array}{l}0.0105^{* *} \\
(0.00)\end{array}$ \\
\hline Female/male employment rate (\%) & & & & & & $\begin{array}{l}0.0028 \\
(0.01)\end{array}$ \\
\hline Unemployment, female (\%) & & & & & & $\begin{array}{l}0.0011 \\
(0.00)\end{array}$ \\
\hline Constant & $\begin{array}{l}-16.7359 \\
(67.87)\end{array}$ & $\begin{array}{l}-114.5816^{\circ} \\
(48.38)\end{array}$ & $\begin{array}{l}77.4711 \\
(58.92)\end{array}$ & $\begin{array}{l}-33.2145 \\
(173.28)\end{array}$ & $\begin{array}{l}-46.0263 \\
(68.19)\end{array}$ & $\begin{array}{l}-234.7473^{* * *} \\
(9.54)\end{array}$ \\
\hline No. of observations[Country-years] & 138 & 59 & 132 & 22 & 119 & 25 \\
\hline No. of groups[Countries] & 6 & 4 & 6 & 6 & 6 & 5 \\
\hline
\end{tabular}

${ }^{\circ} \mathrm{p}<0.10,{ }^{*} \mathrm{p}<0.05,{ }^{* *} \mathrm{p}<0.01,{ }^{* * *} \mathrm{p}<0.001$

Note: Dependent variable: total fertility rate. Privatization is lagged one year.

All models are adjusted for countries' population size and time trend.

Cluster-robust standard errors are in parentheses 


\section{References}

Aassve, Arnstein, Francesco C. Billari and Zsolt Spéder. 2006. "Societal Transition, Policy Changes and Family Formation: Evidence from Hungary.” European Journal of Population 22(2):127-52.

Aassve, Arnstein, Maria Sironi and Vittorio Bassi. 2013. "Explaining Attitudes Towards Demographic Behaviour.” European Sociological Review 29(2):316-33.

Adler, Marina A. 1997. "Social Change and Declines in Marriage and Fertility in Eastern Germany.” Journal of Marriage and Family 59(1):37-49.

Aksoy, Ozan and Francesco C. Billari. 2018. "Political Islam, Marriage, and Fertility: Evidence from a Natural Experiment.” American Journal of Sociology 123(5):1296-340.

Allison, Paul D. 2010. “When Can You Safely Ignore Multicollinearity?”. Statistical Horizons Blog, 10 September 2010, https://statisticalhorizons.com/multicollinearity.

Arpino, Bruno, Gøsta Esping-Andersen and Léa Pessin. 2015. "How Do Changes in Gender Role Attitudes Towards Female Employment Influence Fertility? A Macro-Level Analysis.” European Sociological Review 31(3):370-82.

Axinn, William G. and Jennifer S. Barber. 2001. "Mass Education and Fertility Transition.” American Sociological Review 66(4):481-505.

Azarova, Aytalina, Darja Irdam, Alexi Gugushvili, Mihaly Fazekas, Gábor Scheiring, Pia Horvat, Denes Stefler, Irina Kolesnikova, Vladimir Popov, Iván Szelényi, David Stuckler, Michael Marmot, Michael Murphy, Martin McKee, Martin Bobak and Lawrence King. 2017. “The Effect of Rapid Privatisation on Mortality in Mono-Industrial Towns in Post-Soviet Russia: A Retrospective Cohort Study.” The Lancet Public Health 2(5):e231-e38. 
Balbo, Nicoletta, Francesco C. Billari and Melinda Mills. 2013. "Fertility in Advanced Societies: A Review of Research.” European Journal of Population 29(1):1-38.

Bandelj, Nina and Matthew C. Mahutga. 2010. "How Socio-Economic Change Shapes Income Inequality in Post-Socialist Europe.” Social Forces 88(5):2133-61.

Bartha, Eszter. 2013. Alienating Labour: Workers on the Road from Socialism to Capitalism in East Germany and Hungary. Oxford and New York: Berghahn Books.

Bartus, Tamás, Lívia Murinkó, Ivett Szalma and Bernadett Szél. 2013. “The Effect of Education on Second Births in Hungary: A Test of the Time-Squeeze, Self-Selection, and PartnerEffect Hypotheses.” Demographic research 28:1-32.

Bhattacharya, Tithi, ed. 2017. Social Reproduction Theory: Remapping Class, Recentering Oppression. London: Pluto Press.

Billingsley, Sunnee. 2010. “The Post-Communist Fertility Puzzle.” Population Research and Policy Review 29(2):193-231.

Billingsley, Sunnee and Aija Duntava. 2017. "Putting the Pieces Together: 40 Years of Fertility Trends across 19 Post-Socialist Countries.” Post-Soviet Affairs 33(5):389-410.

Birdsall, Nancy and John Nellis. 2003. "Winners and Losers: Assessing the Distributional Impact of Privatization.” World Development 31(10):1617-33.

Black, Richard, Godfried Engbersen and Marek Okólski, eds. 2010. A Continent Moving West? EU Enlargement and Labour Migration from Central and Eastern Europe. Amsterdam: Amsterdam University Press.

Bohle, Dorothee. 2014. "Post-Socialist Housing Meets Transnational Finance: Foreign Banks, Mortgage Lending, and the Privatization of Welfare in Hungary and Estonia.” Review of International Political Economy 21(4):913-48. 
Bollen, Kenneth A., Jennifer L. Glanville and Guy Stecklov. 2007. "Socio-Economic Status, Permanent Income, and Fertility: A Latent-Variable Approach.” Population Studies 61(1):15-34.

Bongaarts, John. 2001. "Fertility and Reproductive Preferences in Post-Transitional Societies.” Population and Development Review 27:260-81.

Brauner-Otto, Sarah R., William G. Axinn and Dirgha J. Ghimire. 2007. “The Spread of Health Services and Fertility Transition.” Demography 44(4):747-70.

Brewster, Karin L. and Ronald R. Rindfuss. 2000. “Fertility and Women’s Employment in Industrialized Nations.” Annual Review of Sociology 26(1):271-96.

Brinton, Mary C. and Eunsil Oh. 2019. “Babies, Work, or Both? Highly Educated Women’s Employment and Fertility in East Asia.” American Journal of Sociology 125(1):105-40.

Bühler, Christoph and Ewa Fratczak. 2007. "Learning from Others and Receiving Support: The Impact of Personal Networks on Fertility Intentions in Poland.” European Societies 9(3):359-82.

Burawoy, Michael and Katherine Verdery. 1999. Uncertain Transition: Ethnographies of Change in the Postsocialist World. Lanham: Rowman \& Littlefield.

Champlin, Dell. 1999. "Social Capitaland the Privatization of Public Goods.” International Journal of Social Economics 26(10/11):1302-14.

Cherlin, Andrew J., David C. Ribar and Suzumi Yasutake. 2016. "Nonmarital First Births, Marriage, and Income Inequality.” American Sociological Review 81(4):749-70.

Cook, Linda J. 2007. Postcommunist Welfare States: Reform Politics in Russia and Eastern Europe. Ithaca \& London: Cornell University Press. 
Cornia, Giovanni A. and Renato Paniccia. 1995. Demographic Impact of Sudden Impoverishment: Eastern Europe During the 1989-94 Transition. UNICEF Innocenti Research Centre: Innocenti Occasional Papers, Economic Policy Series 49

Craig, Lyn and Killian Mullan. 2011. "How Mothers and Fathers Share Childcare:A CrossNational Time-Use Comparison.” American Sociological Review 76(6):834-61.

Cuadrado-Ballesteros, Beatriz and Noemí Peña-Miguel. 2018. “The Socioeconomic Consequences of Privatization: An Empirical Analysis for Europe.” Social Indicators Research 139(1):163-83.

Eberstadt, Nicholas. 1994. "Demographic Shocks in Eastern Germany, 1989-93.” Europe-Asia Studies 46(3):519-33.

Ellman, Michael. 2000. "The Social Costs and Consequences of the Transformation Process." Economic Survey of Europe 2000(2-3):125-40.

Esping-Andersen, Gosta. 1990. The Three Worlds of Welfare Capitalism. Cambridge: Polity Press. Esping-Andersen, Gosta. 2009. Incomplete Revolution: Adapting Welfare States to Women's New Roles. Cambridge: Polity.

Esping-Andersen, Gøsta and Francesco C. Billari. 2015. "Re-Theorizing Family Demographics.” Population and Development Review 41(1):1-31.

Estrin, Saul and Adeline Pelletier. 2018. "Privatization in Developing Countries: What Are the Lessons of Recent Experience?”. The World Bank Research Observer 33(1):65-102.

Eurostat. 2020. “General Government Expenditure by Function [Cofog].” Eurostat, gov_10a_exp, URL: http://appsso.eurostat.ec.europa.eu/nui/show.do?dataset=gov_10a_exp\&lang=eng (last access: 20/Mar/2020). 
Fodor, Eva. 2003. Working Difference: Women's Working Lives in Hungary and Austria, 19451995. Durham, N.C.: Duke University Press.

Fodor, Éva. 2002. “Smiling Women and Fighting Men: The Gender of the Communist Subject in State Socialist Hungary.” Gender \& Society 16(2):240-63.

Fodor, Éva. 2004. “The State Socialist Emancipation Project: Gender Inequality in Workplace Authority in Hungary and Austria.” Signs: Journal of Women in Culture and Society 29(3):783-813.

Fodor, Éva and Dániel Horn. 2015. “'Economic Development’ and Gender Equality: Explaining Variations in the Gender Poverty Gap after Socialism.” Social Problems 62(2):286-308.

Franklin, Sarah and Faye Ginsburg. 2019. "Reproductive Politics in the Age of Trump and Brexit.” Cultural Anthropology 34(1):3-9.

Fraser, Nancy. 1994. “After the Family Wage: Gender Equity and the Welfare State.” Political Theory 22(4):591-618.

Fraser, Nancy. 2013. Fortunes of Feminism: From State-Managed Capitalism to Neoliberal Crisis. London: Verso Books.

Fraser, Nancy. 2014. “Can Society Be Commodities All the Way Down? Post-Polanyian Reflections on Capitalist Crisis.” Economy and Society 43(4):541-58.

Frejka, Tomas and Stuart Gietel-Basten. 2016. "Fertility and Family Policies in Central and Eastern Europe after 1990.” Comparative Population Studies 41(1):3-56.

Gerber, Theodore P. and Brienna Perelli-Harris. 2012. "Maternity Leave in Turbulent Times: Effects on Labor Market transitions and Fertility in Russia, 1985-2000.” Social Forces 90(4):1297-322. 
Glass, Jennifer, Robin W. Simon and Matthew A. Andersson. 2016. "Parenthood and Happiness: Effects of Work-Family Reconciliation Policies in 22 OECD Countries.” American Journal of Sociology 122(3):886-929.

Gold, Rachel, Bruce Kennedy, Fred Connell and Ichiro Kawachi. 2002. "Teen Births, Income Inequality, and Social Capital: Developing an Understanding of the Causal Pathway.” Health \& Place 8(2):77-83.

Gregor, Anikó and Eszter Kováts. 2019. “Work-Life: Balance? Tensions between Care and Paid Work in the Lives of Hungarian Women.” Social Science Review 2019(7).

Gupta, Nandini, Jhon C. Ham and Jan Svejnar. 2008. "Priorities and Sequencing in Privatization: Evidence from Czech Firm Panel Data.” European Economic Review 52(2):183-208.

Hamm, Patrick, Lawrence King and David Stuckler. 2012. "Mass Privatization, State Capacity, and Economic Growth in Post-Communist Countries.” American Sociological Review 77(2):295-324.

Haney, Lynne. 2002. Inventing the Needy: Gender and the Politics of Welfare in Hungary: Univ of California Press.

Hann, Chris, ed. 2002. Postsocialism: Ideals, Ideologies and Practices in Eurasia. London: Routledge.

Harknett, Kristen, Daniel Schneider and Sigrid Luhr. 2020. "Who Cares If Parents Have Unpredictable Work Schedules?: Just-in-Time Work Schedules and Child Care Arrangements.” Social Problems.

Hendi, Arun S. 2017. “Globalization and Contemporary Fertility Convergence.” Social Forces 96(1):215-38. 


\section{Privatisation and fertility}

Hollos, Marida and Laura Bernardi. 2009. "Post-Socialist Uncertainty: Childbearing Decisions in Hungary.” Ethnology 48(4):315-36.

Hook, Jennifer L. and Eunjeong Paek. 2020. “National Family Policies and Mothers’ Employment: How Earnings Inequality Shapes Policy Effects across and within Countries.” American Sociological Review Published online (1 June 2020).

Irdam, D., L. King, A. Gugushvili, A. Azarova, M. Fazekas, G. Scheiring, D. Stefler, K. Doniec, P. Horvat, I. Kolesnikova, V. Popov, I. Szelenyi, M. Marmot, M. Murphy, M. McKee and M. Bobak. 2016. “Mortality in Transition: A Multilevel Indirect Demographic Cohort Study Privmort.” BMC Public Health 16(672):1-8.

Jackson, Michelle V and Geoffrey Evans. 2017. “Rebuilding Walls: Market Transition and Social Mobility in the Post-Socialist Societies of Europe.” Sociological Science 4:54-79.

Johnston, Ron, Kelvyn Jones and David Manley. 2018. "Confounding and Collinearity in Regression Analysis: A Cautionary Tale and an Alternative Procedure, Illustrated by Studies of British Voting Behaviour.” Quality \& Quantity 52(4):1957-76.

Kalleberg, Arne L. 2009. "Precarious Work, Insecure Workers: Employment Relations in Transition.” American Sociological Review 74(1):1-22.

Kamarás, Ferenc. 2003. “Fertility Preferences Versus Actual Behaviour in Hungary.” Pp. 165-88 in Population of Central and Eastern Europe: Challenges and Opportunities - Proceedings of the European Population Conference Warsaw, 26-30 August 2003, edited by I. E. Kotowska and J. Jóźwiak. Warsaw: Statistical Publishing Establishment.

Kapitány, Balázs and Zsolt Spéder. 2018. “Gyermekvállalás.” Pp. 47-64 in Demográfiai Portré 2018, edited by J. Monostori, P. Öri and Z. Spéder. Budapest: KSH Népességtudományi Kutatóintézet. 
Kikeri, Sunita. 1997. "Privatization and Labor: What Happens to Workers When Governments Divest?”. World Bank Technical Paper, 396, Washington DC, The World Bank.

King, Lawrence. 2000. “Foreign Direct Investment and Transition.” European Journal of Sociology 41(02):227-58.

King, Lawrence, David Stuckler and Patrick Hamm. 2006. "Mass Privatization and the Postcommunist Mortality Crisis.” PERI Working Paper Series, Nr. 118, Political Economy Research Institute, University of Massachusetts Amherst.

King, Lawrence, Patrick Hamm and David Stuckler. 2009. "Rapid Large-Scale Privatization and Death Rates in Ex-Communist Countries: An Analysis of Stress-Related and Health System Mechanisms.” International journal of health services : planning, administration, evaluation 39(3):461-89.

Kohler, Hans-Peter, Francesco C. Billari and José Antonio Ortega. 2002. "The Emergence of Lowest-Low Fertility in Europe During the 1990s.” Population and Development Review 28(4):641-80.

Kohler, Hans-Peter and Iliana Kohler. 2002. "Fertility Decline in Russia in the Early and Mid 1990s: The Role of Economic Uncertainty and Labour Market Crises.” European Journal of Population 18(3):233-62.

Kornai, Janos. 1986. “The Soft Budget Constraint.” Kyklos 39(1):3-30.

Kornai, János. 1980. Economics of Shortage. Amsterdam: North Holland Publishing Company.

Kravdal, Øystein and Ronald R. Rindfuss. 2008. “Changing Relationships between Education and Fertility: A Study of Women and Men Born 1940 to 1964.” American Sociological Review 73(5):854-73. 


\section{Privatisation and fertility}

Kreyenfeld, Michaela. 2010. “Uncertainties in Female Employment Careers and the Postponement of Parenthood in Germany.” European Sociological Review 26(3):351-66.

Lesthaeghe, Ron and Johan Surkyn. 2002. “New Forms of Household Formation in Central and Eastern Europe: Are They Related to Newly Emerging Value Orientations?’. Interuniversity papers in demography, Interface Demography, Vrije Universiteit Brussels, IPD-WP 2002-2, Brussels.

Macura, M, A Kadri, Y Mochizaki-Sternberg and J. L. Garcia. 2000. "Fertility Decline in the Transition Economies, 1989-1998: Economic and Social Factors Revisited.” Pp. 189-207 in Economic Survey in Europe, 2000/1, edited by M. Macura, A. Kadri, Y. MochizakiSternberg and J. L. Garcia. New York and Geneva: UN Economic Commission for Europe.

Mahutga, Matthew C. and Andrew K. Jorgenson. 2016. "Production Networks and Varieties of Institutional Change: The Inequality Upswing in Post-Socialism Revisited.” Social Forces 94(4):1711-41.

Mahutga, Matthew C., Anthony Roberts and Ronald Kwon. 2017. "The Globalization of Production and Income Inequality in Rich Democracies.” Social Forces 96(1):181-214.

Matysiak, Anna and Daniele Vignoli. 2008. “Fertility and Women’s Employment: A MetaAnalysis.” European Journal of Population 24(4):363-84.

Mcdonald, Peter. 2006. "Low Fertility and the State: The Efficacy of Policy.” Population and Development Review 32(3):485-510.

McKenzie, David, Dilip Mookherjee, Gonzalo Castañeda and Jaime Saavedra. 2003. “The Distributive Impact of Privatization in Latin America: Evidence from Four Countries [with Comments].” Economía 3(2):161-233. 
Melegh, Attila. 2016. “Unequal Exchanges and the Radicalization of Demographic Nationalism in Hungary.” Intersections. East European Journal of Society and Politics 2(4):87-108.

Mills, Melinda and Hans-Peter Blossfeld. 2005. “Globalization, Uncertainty and the Early Life Course. A Theoretical Framework.” Pp. 1-24 in Globalization, Uncertainty and Youth in Society, edited by H.-P. Blossfeld, E. Klijzing, M. Mills and K. Kurz. London: Routledge.

Nargund, Vinod H. 2015. "Effects of Psychological Stress on Male Fertility.” Nature Reviews Urology 12(7):373-82.

Oláh, Livia Sz and Eva M. Bernhardt. 2008. “Sweden: Combining Childbearing and Gender Equality.” Demographic research 19:1105-44.

Oláh, Livia Sz. 2003. “Gendering Fertility: Second Births in Sweden and Hungary.” Population Research and Policy Review 22(2):171-200.

Oppenheimer, Valerie Kincade. 1988. “A Theory of Marriage Timing.” American Journal of Sociology 94(3):563-91.

Orloff, Ann Shola. 1993. "Gender and the Social Rights of Citizenship: The Comparative Analysis of Gender Relations and Welfare States.” American Sociological Review 58(3):303-28.

Pan, Li and Jianguo Xu. 2012. “Housing Price and Fertility Rate.” China Economic Journal 5(23):97-111.

Perelli-Harris, Brienna. 2008. "Family Formation in Post-Soviet Ukraine: Changing Effects of Education in a Period of Rapid Social Change.” Social Forces 87(2):767-94.

Pesando, Luca Maria. 2019. “Childlessness and Upward Intergenerational Support: CrossNational Evidence from 11 European Countries.” Ageing and Society 39(6):1219-54. 


\section{Privatisation and fertility}

Philipov, Dimiter and Hans-Peter Kohler. 2001. “Tempo Effects in the Fertility Decline in Eastern Europe: Evidence from Bulgaria, the Czech Republic, Hungary, Poland, and Russia.” European Journal of Population 17(1):37-60.

Philipov, Dimiter, Zsolt Spéder and Francesco C. Billari. 2006. “Soon, Later, or Ever? The Impact of Anomie and Social Capital on Fertility Intentions in Bulgaria [2002] and Hungary [2001].” Population Studies 60(3):289-308.

Rabe-Hesketh, Sophia and Anders Skrondal. 2012. Multilevel and Longitudinal Modeling Using Stata [2 Vols.]: STATA press.

Ramamurti, Ravi. 1997. “Testing the Limits of Privatization: Argentine Railroads.” World Development 25(12):1973-93.

Rindfuss, Ronald R., Karen Benjamin Guzzo and S. Philip Morgan. 2003. "The Changing Institutional Context of Low Fertility.” Population Research and Policy Review 22(5):41138.

Rotariu, Traian. 2006. "Romania and the Second Demographic Transition: The Traditional Value System and Low Fertility Rates.” International Journal of Sociology 36(1):10-27.

Savas, Emanuel S. 2000. Privatization and Public-Private Partnerships. London \& New York: Chatham House.

Scheiring, Gábor, Dénes Stefler, Darja Irdam, Mihály Fazekas, Aytalina Azarova, Irina Kolesnikova, János Köllő, Vladimir Popov, Iván Szelényi, Michael Marmot, Michael Murphy, Martin McKee, Martin Bobak and Lawrence King. 2018. “The Gendered Effects of Foreign Investment and Prolonged State Ownership on Mortality in Hungary: An Indirect Demographic, Retrospective Cohort Study.” The Lancet Global Health 6(1):95102. 


\section{Privatisation and fertility}

Scheiring, Gábor, Darja Irdam and Lawrence King. 2019. “Cross-Country Evidence on the Social Determinants of the Post-Socialist Mortality Crisis in Europe: A Review and PerformanceBased Hierarchy of Variables.” Sociology of Health \& Illness 41(4):673-91.

Scheiring, Gábor. 2020. “Left Behind in the Hungarian Rustbelt: The Cultural Political Economy of Working-Class Neo-Nationalism.” Sociology Special Issue (Nationalism’s Futures).

Scheiring, Gábor, Aytalina Azarova and Darja Irdam. 2020a. “Analyzing the Health Impact of Economic Change: Insights from a Multi-Level Retrospective Cohort Study.” SAGE Research Methods Cases: Medicine and Health, doi: https://dx.doi.org/10.4135/9781529711189.

Scheiring, Gábor, David Stuckler and Lawrence King. 2020b. "Deindustrialization and Deaths of Despair: Mapping the Impact of Industrial Decline on Ill Health.” Political Economy Research Institute (PERI), Working Paper Series, Number 530, November 30, 2020., University of Massachusetts, Amherst.

Scheiring, Gábor and Kristóf Szombati. 2020. "From Neoliberal Disembedding to Authoritarian Re-Embedding: The Making of Illiberal Hegemony in Hungary.” International Sociology Published online (18 Aug 2020).

Schmidt, Manfred G and Gerhard A Ritter, eds. 2013. The Rise and Fall of a Socialist Welfare State: The German Democratic Republic [1949-1990] and German Unification [19891994]. Berlin \& Heidelberg: Springer-Verlag.

Schneider, Daniel and Kristen Harknett. 2020. "Hard Times: Routine Schedule Unpredictability and Material Hardship among Service Sector Workers.” Social Forces Published Online(11 Aug 2020). 


\section{Privatisation and fertility}

Sobotka, Tomas. 2011. “Fertility in Central and Eastern Europe after 1989: Collapse and Gradual Recovery.” Historical Social Research 36(2):246-96.

Sobotka, Tomáš. 2003. “Re-Emerging Diversity: Rapid Fertility Changes in Central and Eastern Europe after the Collapse of the Communist Regimes.” Population 58(4):451 - 86.

Spéder, Zsolt. 2006. "Rudiments of Recent Fertility Decline in Hungary: Postponement, Educational Differences, and Outcomes of Changing Partnership Forms.” Demographic research 15(8):253-88.

Spéder, Zsolt and Ferenc Kamarás. 2008. "Hungary: Secular Fertility Decline with Distinct Period Fluctuations.” Demographic research 19(18):599-664.

Spéder, Zsolt and Balázs Kapitány. 2009. “How Are Time-Dependent Childbearing Intentions Realized? Realization, Postponement, Abandonment, Bringing Forward.” European Journal of Population 25(4):503.

Spéder, Zsolt and Balázs Kapitány. 2014. “Failure to Realize Fertility Intentions: A Key Aspect of the Post-Communist Fertility Transition.” Population Research and Policy Review 33(3):393-418.

Spéder, Zsolt and Tamás Bartus. 2017. "Educational Enrolment, Double-Status Positions and the Transition to Motherhood in Hungary.” European Journal of Population 33(1):55-85.

Stošić, Ivan, Srđan Redžepagić and Zvonko Brnjas. 2012. "Privatization, Restructuring and Unemployment: The Case of Serbia.” Pp. 355-72 in New Challenges in Changing Labour Markets, edited by J. Zubović and I. Domazet. Belgrade: Institute of Economic Sciences.

Streeck, Wolfgang. 1987. “The Uncertainties of Management in the Management of Uncertainty: Employers, Labor Relations and Industrial Adjustment in the 1980s.” Work, employment and society 1(3):281-308. 


\section{Privatisation and fertility}

Stuckler, David, Lawrence King and Martin McKee. 2009. "Mass Privatisation and the PostCommunist Mortality Crisis: A Cross-National Analysis.” The Lancet 373(9661):399-407. Szalma, Ivett and Judit Takács. 2018. “Is There Voluntary Childlessness at All in Hungary?” Pp. 309-36 in Voluntary and Involuntary Childlessness (Emerald Studies in Reproduction, Culture and Society), edited by N. Sappleton. Bingley: Emerald Publishing Limited.

Szelényi, Iván. 1983. Urban Inequalities under State Socialism. Oxford: Oxford University Press. Szelényi, Iván. 1991. “Karl Polanyi and the Theory of a Socialist Mixed Economy.” Pp. 231-48 in The Legacy of Karl Polanyi: Market, State and Society at the End of the Twentieth Century, edited by M. Mendell and D. Salée. Houndmills: Palgrave Macmillan.

Tálas, Péter. 2020. “Demographic and Migration Trends in Hungary.” Pp. 65-78 in Demography and Migration in Central and Eastern Europe, edited by P. Tálas and A. Etl. Budapest: Dialog Campus.

Thornton, Arland and Dimiter Philipov. 2009. "Sweeping Changes in Marriage, Cohabitation and Childbearing in Central and Eastern Europe: New Insights from the Developmental Idealism Framework.” European Journal of Population 25(2):123-56.

United Nations. 2017. "World Population Prospects: The 2017 Revision, Key Findings and Advance Tables.” The Department of Economic and Social Affairs, United Nations, Working Paper No. ESA/P/WP/248, New York.

Vignoli, Daniele, Francesca Rinesi and Eleonora Mussino. 2013. “A Home to Plan the First Child? Fertility Intentions and Housing Conditions in Italy.” Population, Space and Place 19(1):60-71.

Vos, Allison E. 2009. “Falling Fertility Rates: New Challenges to the European Welfare State.” Socio-Economic Review 7(3):485-503. 
Privatisation and fertility

World Bank. 2020. “World Development Indicators.” The World Bank, Washington D.C., URL:

http://data.worldbank.org/data-catalog/world-development-indicators $\quad$ (last access: 23/Mar/2020). 